\title{
P2X7R in Mast Cells is a Potential Target for Salicylic Acid and Aspirin in Treatment of Inflammatory Pain
}

\author{
Yucui Jiang ${ }^{1,2, *}$ \\ Fan $\mathrm{Ye}^{\mathrm{l}, *}$ \\ Ying Du' \\ Yingxin Zong' \\ Zongxiang Tang $\mathbb{D}^{1}$
}

'School of Medicine \& Holistic Integrative Medicine, Nanjing University of Chinese Medicine, Nanjing, Jiangsu, People's Republic of China; ${ }^{2}$ School of Chinese Medicine \& School of Integrated Chinese and Western Medicine, Nanjing University of Chinese Medicine, Nanjing, Jiangsu, People's Republic of China

*These authors contributed equally to this work
Correspondence: Zongxiang Tang School of Medicine \& Holistic Integrative Medicine, Nanjing University of Chinese Medicine, I 38 Xianlin Avenue, Nanjing, Jiangsu Province

Tel +86258581 I802

Email zongxiangtang@njutcm.edu.cn
Background: Mast cells are well known for their role in inflammatory pain. P2X7 receptor (P2X7R) has attracted much attention due to its prominent role in inflammatory diseases. Salicylates are commonly used anti-inflammatory and analgesic drugs. Until now, little has been known about whether P2X7R in mast cells is involved in inflammatory pain and whether it is a potential target for salicylates.

Methods: First, the expression of $\mathrm{P} 2 \mathrm{X}$ receptors in mouse peritoneal mast cells was detected by using RT-PCR, immunofluorescence, calcium imaging and electrophysiological technique. In addition, the functions of $\mathrm{P} 2 \mathrm{X}$ receptors, especially $\mathrm{P} 2 \mathrm{X} 7 \mathrm{R}$, in mast cells were studied by using QPCR, ELISA and behavioral tests. Furthermore, P2X7R was used as a target to screen for some anti-inflammatory monomers that could inhibit its activity. At last, the effect of salicylic acid (SA) and aspirin (ASA) on the activity of P2X7R was studied by using calcium imaging, electrophysiological technique, ELISA, real-time PCR, behavioral tests, immunofluorescence and molecular docking.

Results: We found that P2X1, P2X3, P2X4 and P2X7 receptors were expressed in mouse peritoneal mast cells. The functions of different $\mathrm{P} 2 \mathrm{X}$ receptors were various. Activation of $\mathrm{P} 2 \mathrm{X} 7 \mathrm{R}$ in mouse mast cells induced the release of inflammatory mediators, such as histamine, IL-1 $\beta$, and CCL3. In addition, inflammation pain induced by high concentrations of ATP could be alleviated by P2X7R blockers or mast cell defects. Interestingly, SA or ASA could reduce high concentrations of ATP-induced inward current, P2X7R upregulation, mediators release, and inflammatory pain. SA or ASA also inhibited the inward current evoked by P2X7R agonist, BZATP. Molecular docking showed that SA or ASA had affinity for the cytoplasmic GDP-binding region of P2X7R.

Conclusion: P2X7R in mast cells was involved in inflammation pain by releasing inflammatory mediators, and P2X7R might be a potential target for SA and ASA analgesia.

Keywords: P2X7R, mast cells, salicylates, analgesia, inflammatory pain

\section{Introduction}

Mast cells are in close proximity to afferents and establish dynamic interactions with pain-activating nociceptors. ${ }^{1}$ Preformed and newly synthesized mediators released from mast cells, including proteoglycans, proteases, leukotrienes, biogenic amines, and cytokines, contribute to pain via nervous system or other immune cells. Therefore, mast cells play important roles in the pathological process of pain. ${ }^{2,3}$ The classic pathway for mast cells activation is mediated by IgE receptor (FceRI). ${ }^{4}$ In addition, mast cells are also activated by a wide variety of triggers, such as substance P, lipid mediators, interleukins and extracellular ATP. ${ }^{5,6}$ 
Extracellular ATP is a "signal of danger" mediated by $\mathrm{P} 2$ purinergic receptors. $\mathrm{P} 2$ receptors have two types, $\mathrm{P} 2 \mathrm{X}$ (P2X1-7) receptors and $\mathrm{P} 2 \mathrm{Y}$ receptors. ${ }^{7} \mathrm{P} 2 \mathrm{X}$ receptors carry out many important functions in the central and peripheral nervous system. ${ }^{8,9}$ Compelling evidence has shown that $\mathrm{P} 2 \mathrm{X} 3, \mathrm{P} 2 \mathrm{X} 4$ and $\mathrm{P} 2 \mathrm{X} 7$ receptors are involved in the pathogenesis of chronic pain. ${ }^{10} \mathrm{P} 2 \mathrm{X} 7 \mathrm{R}$ exists in neurons and glial cells of the nervous system, but is mainly expressed in cells of immune origin such as monocytes, macrophages, and microglia. ${ }^{11}$ The absence of P2X7R can completely eliminate the inflammatory and neuropathic hypersensitivity to both mechanical and temperature stimulation. ${ }^{12-14} \mathrm{P} 2 \mathrm{X} 7 \mathrm{R}$ in microglia plays an important role in chronic neuropathy and inflammatory pain by releasing pro-inflammatory cytokines such as IL$1 \beta .{ }^{15}$ Besides IL-1 $\beta$, the production of cytokines such as IL-6, CCL2, TNF $\alpha$ and CCL3 are also mediated by $\mathrm{P} 2 \mathrm{X} 7 \mathrm{R}$ activation in microglia, neutrophil, and monocytes. ${ }^{16-20} \mathrm{P} 2 \mathrm{X} 7 \mathrm{R}$ is also expressed in a variety of mast cells, including LAD2, HMC-1, BMMCs, MC/9, and P815 mast cells. ${ }^{21}$ Although activation of P2X4R can augment the degranulation mediated by FceRI in mouse bone marrow-derived mast cells, only P2X7R activation contributes to degranulation in LAD2. ${ }^{22,23} \mathrm{P} 2 \mathrm{X} 7 \mathrm{R}$ in mast cells has also recently been proven to be crucial in inflammation diseases such as intestinal inflammation and meningeal neuroinflammation; ${ }^{24,25}$ however, the relationship between P2X7R in mast cells and inflammation pain remains unclear.

Chronic pain is a global problem affecting more than two-thirds of the population. Extensive research has been conducted to find appropriate methods of relieving pain and improving the quality of life. The analgesics include opioids, nonopioid analgesics, and adjuvants or coanalgesics. $^{26}$ Salicylates are effective antiinflammatory, analgesic, and antipyretic agents. Salicylic acid (SA), an extract of willow bark, was used for pain management as early as 4000 years ago. Aspirin (acetylsalicylic acid [ASA]) is the oldest and the most widely used analgesics in the world. ${ }^{27}$ The main mechanism of action of salicylates is to inhibit the cyclooxygenase (COX) and prevent the formation of prostaglandins. ${ }^{28}$ Although the analgesic effect of salicylates is obvious, the targets are still not entirely clear. Previous studies indicate that salicylates are associated with mast cells. SA can significantly inhibit histamine release from rat peritoneal mast cells activated by compound $48 / 80$ or antiDNP IgE. ${ }^{29}$ The relationship between ASA and mast cells remains controversial. Some evidence that shows the anaphylaxis triggered by ASA is due to eosinophils and mast cells. ${ }^{30}$ Although Steinke et al reported that $10 \mathrm{mM}$ ASA alone increased cysteinyl leukotrienes (CysLT) release, Mortaz et al have shown that that $10 \mathrm{mM}$ ASA could inhibit IgE+Ag-mediated mast cells activation. ${ }^{31,32}$ Little is known about the effects of SA or ASA on P2X7R in mast cells.

In the present study, we evaluated the roles of several $\mathrm{P} 2 \mathrm{X}$ receptor subtypes in mouse mast cells, especially P2X7R. In addition, P2X7R was used as a target to screen for some anti-inflammatory monomers that inhibited the activity of P2X7R. Moreover, we also explored the effects of SA and ASA on P2X7R in mast cells.

\section{Materials and Methods}

\section{Ethics Statement}

All procedures were performed under protocols approved by the Animal Care and Use Committee of Nanjing University of Chinese Medicine (ACU190401). This research does not contain any studies with human participants performed by any of the authors.

\section{Animals}

Adult male mice used were $22-26 \mathrm{~g}$ in a C57BL/6 background (Qinglongshan, China). Animals were housed at constant humidity $(40-60 \%)$ and temperature $\left(22 \pm 2{ }^{\circ} \mathrm{C}\right)$ on a $12 \mathrm{~h} \mathrm{light/dark} \mathrm{cycle} \mathrm{and} \mathrm{allowed} \mathrm{free} \mathrm{access} \mathrm{to} \mathrm{food}$ and water. C-kit mutant genetically mast cell-deficient Kit (W-sh) "Sash" mice and Mrgprb2-Cre tdT +mice were donated by Johns Hopkins.

\section{Chemicals}

We used the following chemicals: ATP disodium salt (Sigma-Aldrich, St. Louis, MO, United States), PPADS (20 $\mu \mathrm{M}$, Abcam, USA, a non-selective P2 purinergic receptor antagonist), NF449 (1 $\mu \mathrm{M}$, Cayman, USA, P2X1R antagonist), AF-353 $(0.1 \mu \mathrm{M}$, donated by China Pharmaceutical University, P2X3R antagonist), 5-BDBD (10 $\mu \mathrm{M}$, Sigma-Aldrich, United States, P2X4R antagonist), AZ10606120 (1 $\mu \mathrm{M}$, Tocris Bioscience, USA, P2X7R antagonist), BzATP (30 $\mu \mathrm{M}$, Alomone Labs, Israel, P2X7R agonist), recombinant mouse SCF protein (10 ng/mL, R\&D Systems, USA), penicillin and streptomycin $(100 \mu \mathrm{g} / \mathrm{mL}$; Gibco, USA), fibronectin $(30 \mu \mathrm{g} / \mathrm{mL}$; Sigma-Aldrich, United States), Fluo 4-AM (Solarbio, China, calcium indicator), Histamine ELISA Kit 
(Yifeixue, China), IL-1 $\beta$ ELISA Kit (Yifeixue, China), Trizol (Vazyme Biotech, China), HiScript II Q RT SuperMix for qPCR (Vazyme Biotech, China), Taq MasterMix (Vazyme Biotech, China), AceQ qPCR SYBR Green Master Mix (Vazyme Biotech, China), ATP Content Assay Kit (Yifeixue, China), salicylic acid (Yuanye Biotech, China), aspirin (Yuanye Biotech, China), Rabbit Anti-P2RX7 antibody (Bioss, China)

\section{P8I5 Cells Culture and Mouse Peritoneal Mast Cell Purification}

Mouse mastocytoma cells (P815) were purchased from the Shanghai Institute of Biochemistry and Cell Biology. P815 was cultured in 1640 complete medium (90\% 1640 medium, $10 \%$ fetal bovine serum, $100 \mu \mathrm{g} / \mathrm{mL}$ penicillin and $100 \mu \mathrm{g} / \mathrm{mL}$ streptomycin). Cells were incubated in an incubator humidified with $5 \% \mathrm{CO}_{2}$ at $37{ }^{\circ} \mathrm{C}$.

Mouse peritoneal mast cells were obtained from C57BL/6 mice as Dong's Lab described..$^{33}$ Briefly, the mouse peritoneal cells were collected by mast cell dissociation media MCDM (HBSS with $10 \mathrm{mM}$ HEPES and $3 \%$ fetal bovine serum, $\mathrm{PH}$ was 7.2 ) and centrifuged at 200 $\mathrm{g}$ for $5 \mathrm{~min}$. The pellet was resuspended and layered over $70 \%$ percoll suspension, and then centrifuged at $500 \mathrm{~g}$ at $4^{\circ} \mathrm{C}$ for $20 \mathrm{~min}$. The supernatant was carefully sucked away by pipette and the mast cells were washed with fresh MCDM. Mast cells were resuspended in DMEM containing $10 \%$ fetal bovine serum and $10 \mathrm{ng} / \mathrm{mL}$ recombinant mouse SCF. As Supplementary Figure S1 showed, the isolated mouse peritoneal mast cells were identified by toluidine blue staining and the purity was about $90 \%$.

\section{P2X Purinoceptors RT-PCR Screen}

The TRIzol ${ }^{\circledR}$ method was used to isolate total RNA from mouse peritoneal mast cells or the P815 cells. We used 10500 ng RNA for reverse transcription reaction by using HiScript II Q RT SuperMix for qPCR Kit according to the manufacturer's instructions. Polymerase chain reaction conditions were as follows: $95{ }^{\circ} \mathrm{C}$ for $5 \mathrm{~min}, 40$ cycles of $15 \mathrm{~s}$ at $95^{\circ} \mathrm{C}, 30 \mathrm{~s}$ at $60^{\circ} \mathrm{C}\left(56^{\circ} \mathrm{C}\right.$ for P2X $\left.4 \mathrm{R}\right), 1$ min at $72{ }^{\circ} \mathrm{C}$, and $10 \mathrm{~min}$ at $72{ }^{\circ} \mathrm{C}$. The PCR primers were synthesized by GenScript Biotech (Nanjing, China). The primer sequences and product sizes are shown in Table 1.

\section{Intracellular Calcium Measurement}

Mouse peritoneal mast cells were isolated and placed on slides coated with $30 \mu \mathrm{g} / \mathrm{mL}$ fibronectin. After $2 \mathrm{~h}$ of culture, mast cells were incubated with $1 \mu \mathrm{L} / \mathrm{mL}$ Fluo- 4 and $0.02 \%$ Pluronic F-127 at room temperature for $30 \mathrm{~min}$. The cells then immediately washed 3 times by calcium

Table I The Sequence of Primers and the Size of PCR product

\begin{tabular}{|c|c|c|}
\hline Gene & Primer Sequence $\left(5^{\prime}-3^{\prime}\right)$ & Product Size \\
\hline \multirow[t]{2}{*}{$\mathrm{P} 2 \mathrm{XI}$} & Forward: GCCCAAGGTATTCGCACAGG & \multirow[t]{2}{*}{496 bp } \\
\hline & Reverse: GACGACGGTTTGTCCCATTCT & \\
\hline \multirow[t]{2}{*}{$\mathrm{P} 2 \mathrm{X} 2$} & Forward: ACCTGCCATTTAGATGACGACTG & \multirow[t]{2}{*}{$24 \mathrm{lbp}$} \\
\hline & Reverse: TGTTGCCCTTGGAGAACTTGA & \\
\hline \multirow[t]{2}{*}{$\mathrm{P} 2 \mathrm{X} 3$} & Forward: GCTTCGGACGCTATGCCAACA & \multirow[t]{2}{*}{$490 \mathrm{bp}$} \\
\hline & Reverse: AAATCCTGCCCAGCAAACTTAA & \\
\hline \multirow[t]{2}{*}{$\mathrm{P} 2 \mathrm{X} 4$} & Forward: GTGCTCGGGTCCTTCCTGTTC & \multirow[t]{2}{*}{$154 \mathrm{bp}$} \\
\hline & Reverse: CCGTTTCCTGGTAGCCCTTTT & \\
\hline \multirow[t]{2}{*}{$\mathrm{P} 2 \mathrm{X} 5$} & Forward: TGTAGCGGGACACGGACTGA & \multirow[t]{2}{*}{209 bp } \\
\hline & Reverse: TTTCTAGCACATTGGCTTTGGA & \\
\hline \multirow[t]{2}{*}{$\mathrm{P} 2 \mathrm{X} 6$} & Forward: GGTACAACTTCAGGACAGCCAATC & \multirow[t]{2}{*}{207 bp } \\
\hline & Reverse: CATACAGTAGCAGCAGGTCACAGAG & \\
\hline \multirow[t]{2}{*}{$\mathrm{P} 2 \mathrm{X} 7$} & Forward: AACATCTTGCCAACTATGAACGG & \multirow[t]{2}{*}{132 bp } \\
\hline & Reverse: TCCTCCСTGAACTGCCACCT & \\
\hline
\end{tabular}


imaging buffer $(125 \mathrm{mM} \mathrm{NaCl}, 3 \mathrm{mM} \mathrm{KCl}, 2.5 \mathrm{mM}$ $\mathrm{CaCl}_{2}, 0.6 \mathrm{mM} \mathrm{MgCl}_{2}, 20 \mathrm{mM}$ glucose, $10 \mathrm{mM}$ HEPES, $20 \mathrm{mM}$ sucrose, $1.2 \mathrm{mM} \mathrm{NaHCO}_{3}$, $\mathrm{PH}$ was 7.4). Finally, the cells were imaged at 488-nm excitation to detect intracellular calcium within two hours. Each experiment was done at least three times, and at least 200 cells were analyzed each time.

\section{Whole-Cell Current-Clamp Recordings of Mouse Peritoneal Mast Cells}

All the experiments were performed at room temperature. Whole-cell currents were record by using Multiclamp 700 B and Digidata 1440 A (Molecular Devices, Inc., San Jose, USA). Experiments were performed with a perfusion system, and drugs were directly added to the recording chamber with a pipette. The cells were usually evoked by holding the membrane potential, and applied voltage commands to a range of potentials with $10 \mathrm{mV}$ steps from $-130 \mathrm{mV}$ to $+130 \mathrm{mV}$ duration $100 \mathrm{~ms}$. In addition, currents were evoked by ramping the membrane potential from $-90 \mathrm{mV}$ to $+100 \mathrm{mV}$ duration for $300 \mathrm{~ms}$. The currents were digitized (sampled at a frequency of 10 $\mathrm{kHz}$ and filtered at $0.1 \mathrm{kHz}$ for analysis), stored and subsequently analyzed by using Clampex 10.3 (Molecular Devices, Inc., San Jose, USA). The electrode resistance was 4-6 M , and the osmolality of the pipette solution and external solution was adjusted to 300-310 mOsM (adjusted by sucrose as necessary). The standard pipette solution contained $135 \mathrm{mM} \mathrm{CsCl}, 8 \mathrm{mM} \mathrm{NaCl}, 10 \mathrm{mM}$ EGTA, $3.6 \mathrm{mM} \mathrm{CaCl}_{2}, 10 \mathrm{mM}$ HEPES, $2 \mathrm{mM} \mathrm{Mg-ATP}$ (added when detecting P2X7 channel), $\mathrm{PH}$ was 7.3 (adjusted by $\mathrm{CsOH}$ ). The standard external solution contained $147 \mathrm{mM} \mathrm{NaCl}, 2 \mathrm{mM} \mathrm{KCl}, 2 \mathrm{mM} \mathrm{CaCl} 2,1 \mathrm{mM}$ $\mathrm{MgCl}_{2} \cdot 6 \mathrm{H}_{2} \mathrm{O}, 10 \mathrm{mM}$ HEPES, $16 \mathrm{mM}$ glucose, $\mathrm{PH}$ was 7.3 (adjusted by $\mathrm{NaOH}$ ). Low divalent external solution contained $147 \mathrm{mM} \mathrm{NaCl}, 10 \mathrm{mM}$ HEPES, $13 \mathrm{mM}$ glucose, $0.2 \mathrm{mM} \mathrm{CaCl}_{2}, 2 \mathrm{mM} \mathrm{KCl}, \mathrm{PH}$ was 7.3 (adjusted by $\mathrm{NaOH})$.

\section{Quantitative Real-Time PCR}

P815 Cells (about $10^{5}-10^{6}$ cells) were stimulated by different concentrations of ATP for $0.5,4$, or 8 hours and the paw tissues (10-50 mg) were treated with $100 \mathrm{mM}$ ATP for 1 hour and were collected. Total RNA was extracted by using the TRIzol method. cDNA was generated by using HiScript II Q RT SuperMix for qPCR Kit according to the manufacturer's instruction. Real-time qPCR was performed by using AceQ qPCR SYBR Green Master Mix and GAPDH were used as the internal controls. The primer sequences are shown in Table 2.

\section{ATP Measurement}

ATP was measured by using ATP Content Assay Kit (Yifeixue, China). The principle of ATP content determination is that hexokinase catalyzes glucose and ATP to synthesize glucose-6-phosphate, and glucose-6-phosphate dehydrogenase further catalyzes dehydrogenation of glucose-6-phosphate to form NADPH. NADPH has a characteristic absorption peak at $340 \mathrm{~nm}$, which is proportional to the ATP content. We conducted the experiment according to the manufacturer's instruction. The paw tissue (about $10 \mathrm{mg}$ ) were homogenized and centrifuged at $8000 \mathrm{~g}$ at $4^{\circ} \mathrm{C}$ for $10 \mathrm{~min}$, and the supernatant was collected. After chloroform treatment, the supernatant was collected to detect ATP content.

\section{ELISA}

The concentrations of histamine, CCL3 and IL-1 $\beta$ were determined by ELISA kit (Yifeixue, China). The assay was performed according to the manufacturer's protocol. In brief, mouse peritoneal mast cells were stimulated with different concentrations of ATP. Supernatant was collected after ATP stimulation for $0.5 \mathrm{~h}$ and stored at $80{ }^{\circ} \mathrm{C}$ for histamine detection. The supernatants of P815 cells in control group, ATP group, SA treatment group $(500 \mu \mathrm{M}$, pretreatment for $2 \mathrm{~h})$ and

Table 2 The Sequence of Primers

\begin{tabular}{|l|l|}
\hline \multirow{2}{*}{ Gene } & Primer Sequence (5' $\mathbf{\text { -3' }}$ ) \\
\hline \multirow{2}{*}{ IL-1 $\beta$} & Forward: GTTGCCTTCTTGGGACTGAT \\
\cline { 2 - 2 } & Reverse: CTGGCTTTGTCTTTCTTGTTAT \\
\hline \multirow{2}{*}{ CCL2 } & Forward: AAATCTCGCAGCAGCACATC \\
\cline { 2 - 2 } & Reverse: AGCAGGTTATCATCATCATCCC \\
\hline \multirow{2}{*}{ CCL3 } & Forward: GGCCTGCTGTTCACAGTTGC \\
\cline { 2 - 2 } & Reverse: CAGAAGTGCTTGAGGTGGTTG \\
\hline \multirow{2}{*}{ GAPDH } & Forward: GCTCCCAGCCAGGTGTCATT \\
\cline { 2 - 2 } & Reverse: CAGGCATTCAGTTCCAGGTCAG \\
\hline & Forward: GCACAGTCAAGGCCGAGAAT \\
\cline { 2 - 2 } & Reverse: GCCTTCTCCATGGTGGTGAA \\
\hline
\end{tabular}


ASA treatment group $(1 \mathrm{mM}$, pretreatment for $2 \mathrm{~h})$ was collected and stored at $80{ }^{\circ} \mathrm{C}$ for CCL3 and IL- $1 \beta$ detection.

\section{Pain Model}

Complete Freund's adjuvant (CFA) was injected unilaterally into the plantar surface of one hindpaw in mice (20 $\mu \mathrm{L}$ ), whereas control mice were injected with $0.9 \%$ saline. On the 5th day after CFA injection, the tissue of hindpaw was collected and the ATP content was detected.

\section{Behavioral Assays}

The von Frey behavioral assays were performed in a blinded manner. In brief, different groups of mice were put in a transparent plastic box, which was placed on a metal mesh for about $30 \mathrm{~min}$. Each mouse was tested more than 5 times at a specific force manually, and the threshold was determined by the lowest force needed to elicit responses more than $50 \%$ of the times. The mechanical threshold was measured at $1 \mathrm{~h}, 3 \mathrm{~h}$ and $5 \mathrm{~h}$ after ATP treatment $(100 \mathrm{mM}, \mathrm{PH}$ was $7.32,10 \mu \mathrm{L}$, intradermal injection), respectively. Each mouse was manually tested at a specific force $(0.16 \mathrm{~g})$ at least 10 times.

\section{Histological Assays}

The paw tissue treated with $100 \mathrm{mM}$ ATP for 1 hour was isolated and fixed with $4 \%$ paraformaldehyde for $24 \mathrm{~h}$ and $30 \%$ sucrose for $48 \mathrm{~h}$. The tissue was embedded in OCT and sliced to a thickness of 10 microns, followed by hematoxylin-eosin (HE) staining. Images of each section were obtained by using the Nikon ECLIPSE 80i microscope (Nikon, Tokyo, Japan) with a magnification of 250.

\section{Immunofluorescence Staining}

OCT-embedded paw tissue sections, mouse peritoneal mast cells or P815 cells were fixed by 4\% paraformaldehyde for 10 minutes. After washing 3 times with PBS, sections or P815 cells were blocked with 3\% BSA and incubated in primary antibody solution overnight at $4{ }^{\circ} \mathrm{C}$. After washing 3 times with PBS, sections or P815 cells were incubated with iFluor 488 or 555 goat anti-rabbit IgG for 1 hour at 37 ${ }^{\circ} \mathrm{C}$. Mouse peritoneal mast cells or P815 cells were washed and mounted. The tissue sections were washed and incubated with FITC-avidin for 0.5 hour. Next, sections were washed and mounted in Prolong Gold Antifade Reagent with DAPI. At last, sections were evaluated on Nikon ECLIPSE 80i microscope with a magnification of 250 .

\section{Molecular Docking}

The discovery Studio 20164.0 software was used to verify the molecular docking. We downloaded the threedimensional structure of salicylic acid (PubChem CID: 338) and aspirin (PubChem CID: 2244) from the NCBI PubChem Compound database (http://www.ncbi.nlm.nih. gov/pccompound) and the monomeric crystal structure of P2X7R (PDB ID: 6U9V) from the Research Collaboratory for Structural Bioinformatics (RCSB) Protein Data Bank (http://www.rcsb.org/pdb).

\section{Quantification and Statistical Analysis}

The data were analyzed by GraphPad 8.0 and presented as mean \pm SEM. Statistical analysis of the results was performed by two-tailed, unpaired or paired Student's $t$-test, or one-way ANOVA analysis for comparing all pairs of groups.

\section{Results}

\section{P2X Receptors Expression and ATP-Induced Calcium Response in Mouse Peritoneal Mast Cells}

Extracellular ATP has been reported to increase during tissue stress, hypoxia, or inflammation. Our results showed that ATP was significantly increased in inflammatory pain induced by Complete Freund's adjuvant (Supplementary Figure S2), which may be due to the release of ATP by infiltrating inflammatory cells. In addition, mast cells are known to play important roles in inflammatory pain. Therefore, we suggest that mast cells may be involved in inflammatory pain through the purinergic signaling pathway.

First of all, we explored P2X receptors expression in mouse peritoneal mast cells by using RT-PCR. As shown in Figure 1A, we found that mouse peritoneal mast cells expressed several $\mathrm{P} 2 \mathrm{X}$ receptors including $\mathrm{P} 2 \mathrm{X} 1 \mathrm{R}$, $\mathrm{P} 2 \mathrm{X} 3 \mathrm{R}, \mathrm{P} 2 \mathrm{X} 4 \mathrm{R}$ and $\mathrm{P} 2 \mathrm{X} 7 \mathrm{R}$. P2X receptors are a nonselective cation channel, and its permeability to $\mathrm{Ca}^{2+}$ is the most obvious. Hence, we examined calcium influx induced by ATP in mouse peritoneal mast cells. The results showed that calcium influx in mast cells increased immediately after treatment with ATP (Figure 1B and C). The fluorescence intensity ratio varied with the ATP concentration and the EC50 was about $6.5 \mu \mathrm{M}$ (Figure 1C). In addition to fluorescence intensity, the reaction durations also had differences (Figure 1B, bottom), indicating that different concentrations of ATP activate mast cells through different $\mathrm{P} 2 \mathrm{X}$ receptors. 
A

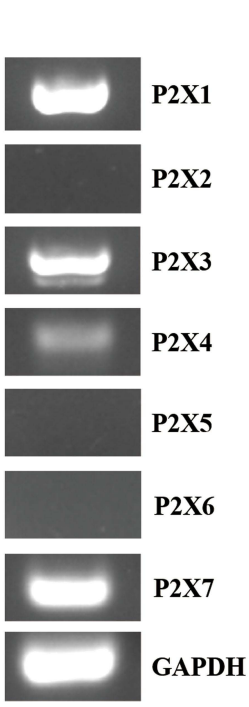

E

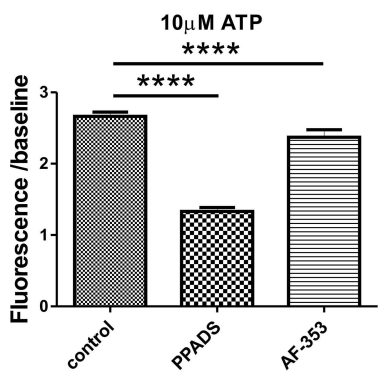

B

control
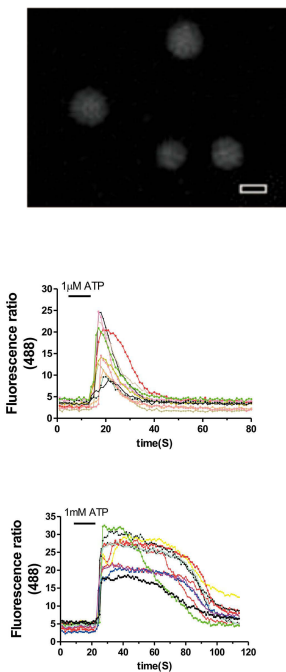

ATP
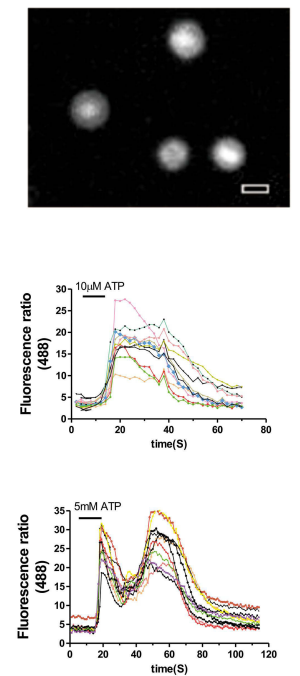

C

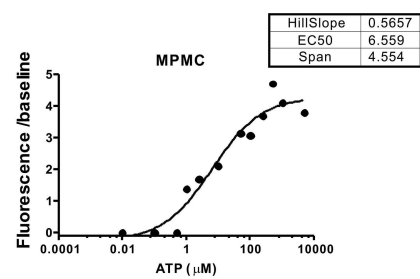

D

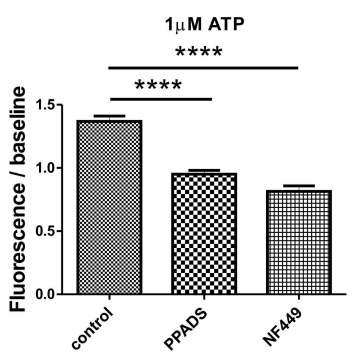

H

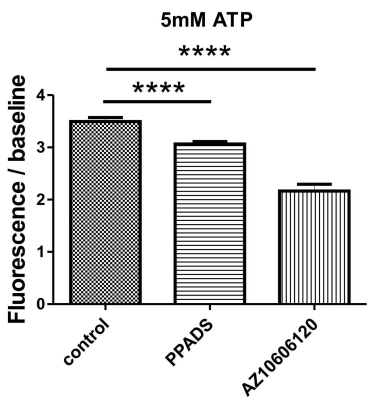

Figure I P2X receptors expression and ATP-induced calcium response in mouse peritoneal mast cells. (A) P2XIR, P2X3R, P2X4R and P2X7R expressed in mouse peritoneal mast cells. (B) Heat map of $\left[\mathrm{Ca}^{2+}\right]$ i (top) and example traces (bottom) mediated by different concentrations of extracellular ATP (Scal bar=10 $\left.\mu \mathrm{m}\right)$. (C) The fluorescence intensity of $\mathrm{Ca}{ }^{2+}$ induced by different concentrations of ATP from 0.01 to $5000 \mu \mathrm{M}$, and the EC50 was about $6.5 \mu \mathrm{M}$. (D) Calcium influx induced by I $\mu$ M ATP was inhibited by PPADS or NF449 (**** $p<$ 0.000 I, control vs PPADS or NF449). (E) Calcium influx induced by $10 \mu M$ ATP was blocked by PPADS or AF-353 (****kp<0.000I, control vs PPADS or AF-353). (F) Calcium influx induced by $100 \mu \mathrm{M}$ ATP was blocked by PPADS or 5-BDBD (****p < $0.000 \mathrm{I}$, control vs PPADS or 5-BDBD). (G) Calcium influx induced by I mM ATP was blocked by PPADS or AZI0606I 20 (****p <0.000I, control vs PPADS or AZ10606I20). (H) Calcium influx induced by 5 mM ATP was blocked by PPADS or AZI 0606 I 20 (**** $p<0.000$ I, control vs PPADS or AZI0606 120). (Statistical analysis of the results was performed by one-way ANOVA analysis followed by Dunn's multiple comparisons test).

To confirm this, we used special P2X channel antagonists. As shown in Figure 1D-H, calcium influx caused by ATP at different concentrations could be partially blocked by nonselective P2 purinergic receptor antagonist PPADS $(20 \mu \mathrm{M}$, pre-incubation for 5 minutes). In addition, calcium influx caused by $1 \mu \mathrm{M}$ ATP was inhibited by P2X1R antagonist NF449 (1 $\mu \mathrm{M}$, pre-incubation for 5 minutes) (Figure 1D). AF-353 (P2X3R antagonist, $0.1 \mu \mathrm{M}$, pre-incubation for 5 minutes) reduced the calcium influx caused by $10 \mu \mathrm{M}$ ATP (Figure 1E). And the transient increase of intracellular calcium induced by $100 \mu \mathrm{M}$ ATP was blocked by 5-BDBD $(10 \mu \mathrm{M}$, pre-incubation for 5 minutes, P2X4R antagonist) (Figure 1F).
In addition, the specific P2X7R antagonist AZ10606120 (1 $\mu \mathrm{M}$, pre-incubation for $5 \mathrm{~min}$ ) could block calcium influx caused by high concentrations of ATP such as $1 \mathrm{mM}$ and 5 $\mathrm{mM}$ (Figure $1 \mathrm{G}$ and $\mathrm{H}$ ). These results suggested that $\mathrm{P} 2 \mathrm{X} 1 \mathrm{R}$, P2X3R, P2X4R and P2X7R might be involved in the activation of mast cells.

\section{Different Inward Currents Evoked by Extracellular ATP in Mouse Peritoneal Mast Cells}

According to published literature, human mast cells are sensitive to ATP in a concentration-dependent manner. ${ }^{6}$ 
A

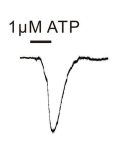

$\underbrace{100 \mathrm{pA}}_{1 \mathrm{~S}}$
B

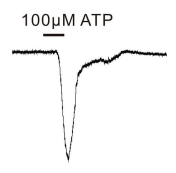

$\prod_{1 \mathrm{~S}}^{100 \mathrm{pA}}$
C

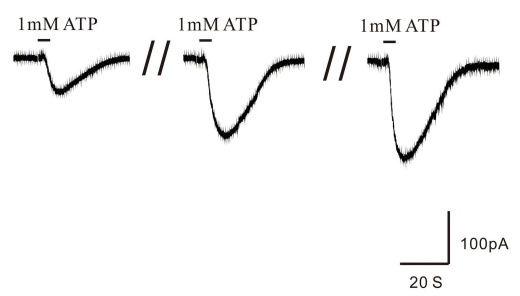

D

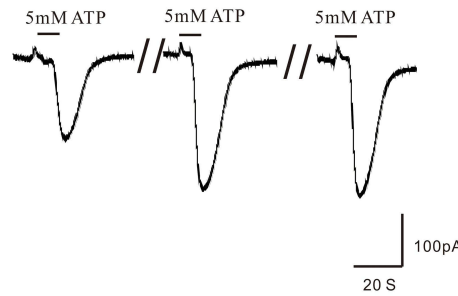

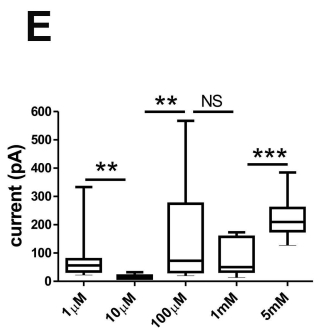

I

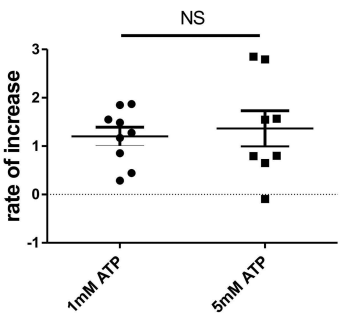

L

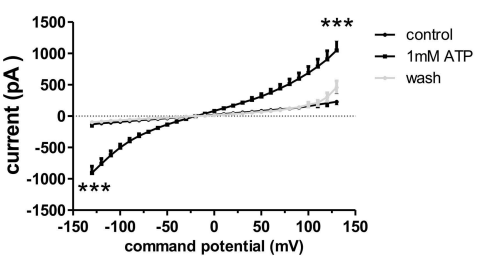

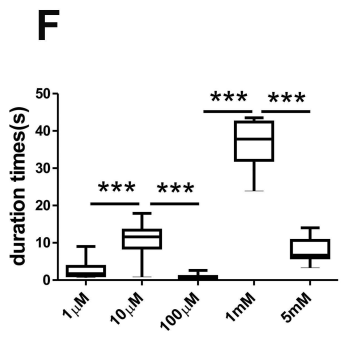

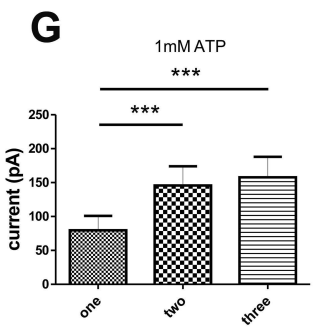

H

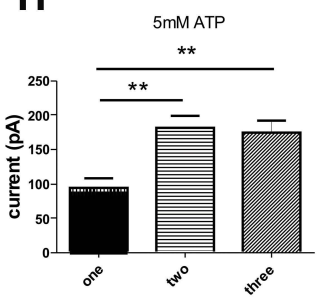

J

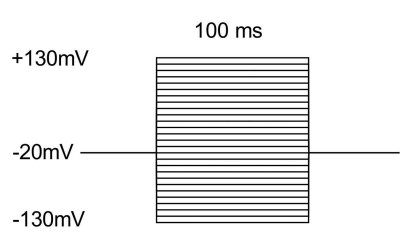

M

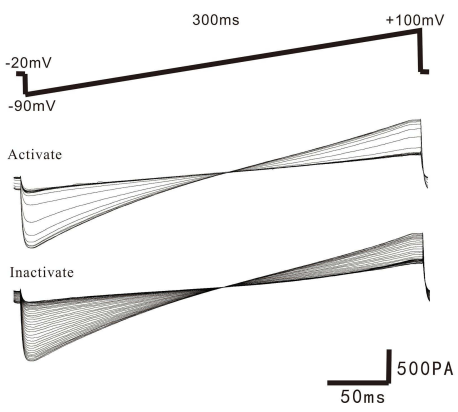

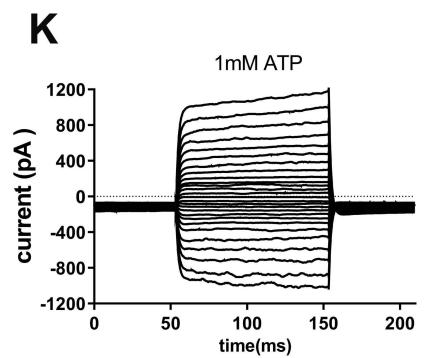

N

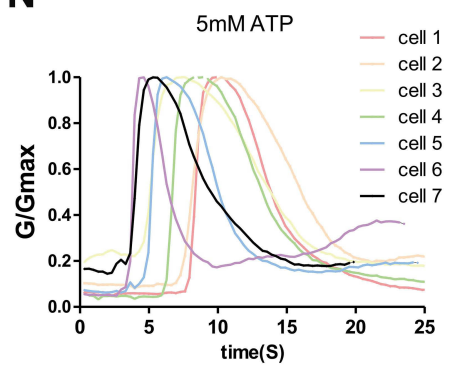

Figure 2 Characteristics of inward currents in mouse peritoneal mast cells evoked by different concentrations of ATP. (A-D) Different currents induced by various concentrations of ATP (I $\mu \mathrm{M}, 100 \mu \mathrm{M}, \mathrm{I} \mathrm{mM}$ and $5 \mathrm{mM}$ ATP respectively). (E) The current amplitude induced by various concentrations of extracellular ATP was different $\left(*^{*} p<0.01\right.$, I $\mu \mathrm{M}$ vs $10 \mu \mathrm{M}$, ${ }^{* * p} p<0.01$, $10 \mu \mathrm{M}$ vs $100 \mu \mathrm{M}$, ***p $<0.00 \mathrm{I}$, I mM vs $5 \mathrm{mM}$, one-way ANOVA analysis followed by Dunnett's multiple comparisons test). (F) The duration of inward currents evoked by different concentrations of extracellular ATP was different (***p $<0.00 \mathrm{I}, \mathrm{I} \mu \mathrm{M}$ vs $10 \mu \mathrm{M}$, I0 $\mu \mathrm{M}$ vs I00 $\mu \mathrm{M}$, I $100 \mu \mathrm{M}$ vs I mM, I mM vs $5 \mathrm{mM}$, one-way ANOVA analysis followed by Dunnett's multiple comparisons test). (G and $\mathbf{H}$ ) The "run-up" tendency of inward currents induced by I mM ATP and $5 \mathrm{mM}$ ATP. (I) No significant changes in the growth rate between I mM ATP- and 5 mM ATP-induced currents. (J) Stimulation protocol. (K) The different currents under this protocol stimulation. (L) The relationship curve of voltage-current. (M) The activate curves and inactivate curves induced by 5 mM ATP. (N) The conductance curve induced by $5 \mathrm{mM}$ ATP.

Our experimental results proved that mouse peritoneal mast cells had the same properties. $1 \mu \mathrm{M}$ ATP (Figure 2A, n=17) and $100 \mu \mathrm{M}$ ATP could induce obvious inward currents in mouse peritoneal mast cells (Figure $2 \mathrm{~B}, \mathrm{n}=21$ ). When we increased the concentration of extracellular ATP to a higher level, we found that both $1 \mathrm{mM}$ ATP and $5 \mathrm{mM}$ ATP had the ability to repeatedly induce inward currents (Figure 2C, $n=9$;
Figure 2D, $n=8$ ). As Figure $2 \mathrm{E}$ and $\mathrm{F}$ showed, the characteristics of the currents induced by different concentrations of ATP were different, including the amplitude and duration of the inward currents. Despite the differences, the inward currents evoked by $1 \mathrm{mM}$ ATP and $5 \mathrm{mM}$ ATP had some similar characteristics, such as "run-up" tendency (Figure 2G and $\mathrm{H}$ ). There was no difference in the current 
growth rate between $1 \mathrm{mM}$ ATP-induced current and $5 \mathrm{mM}$ ATP-induced current, as shown in Figure 2I. The current growth rate is defined as the second current amplitude minus the first current amplitude divided by the first current amplitude. In addition, the inward current evoked by $1 \mathrm{mM}$ ATP was voltage-dependent (Figure 2J-L). Furthermore, the activation curve and inactivation curve induced by $5 \mathrm{mM}$ ATP were shown in Figure 2M. The conductance curves that obtained from these curves were shown in Figure 2N, indicating that the current induced by $5 \mathrm{mM}$ ATP was characterized by fast activation and slow deactivation.

\section{P2XIR, P2X3R, P2X4R and P2X7R Were Expressed in Mouse Peritoneal Mast Cells}

The above results indicate that different concentrations of ATP corresponded to different currents. Therefore, we hypothesized that multiple P2X receptors were involved in the activation progresses. In our study, we found that 1 $\mu \mathrm{M}$ ATP hardly induced inward current when $20 \mu \mathrm{M}$ PPADS (a non-selective P2 antagonist) (Figure 3A and G, $\mathrm{n}=9$ ) or $1 \mu \mathrm{M} \mathrm{NF} 449$ (the blocker of P2X1R) (Figure 3A and $G, n=13$ ) was applied, which indicated that P2X1R was activated by $1 \mu \mathrm{M}$ ATP. As Figure 3B and H showed, $20 \mu \mathrm{M}$ PPADS ( $=9$ ) or $0.1 \mu \mathrm{M}$ AF-353 (the blocker of $\mathrm{P} 2 \mathrm{X} 3$ receptor, $\mathrm{n}=10$ ) could inhibit the current evoked by $10 \mu \mathrm{M}$ ATP, indicating that P2X3R was activated by $10 \mu \mathrm{M}$ ATP. We also found that $\mathrm{P} 2 \mathrm{X} 4 \mathrm{R}$ was involved in the current induced by $100 \mu \mathrm{M}$ ATP, which was blocked by $10 \mu \mathrm{M}$ 5-BDBD (Figure $3 \mathrm{C}$ and $\mathrm{I}, \mathrm{n}=10$ ) or $20 \mu \mathrm{M}$ PPADS (Figure $3 \mathrm{C}$ and $\mathrm{I}, \mathrm{n}=13$ ). The current caused by $1 \mathrm{mM}$ ATP were inhibited by using $1 \mu \mathrm{M}$ AZ 10606120 (the blocker of $\mathrm{P} 2 \mathrm{X} 7$ receptor) (Figure $3 \mathrm{D}$ and $\mathrm{J}, \mathrm{n}=5$ ). The current evoked by $5 \mathrm{mM}$ ATP could also be blocked by 1 $\mu \mathrm{M}$ AZ 10606120 (Figure 3E and $\mathrm{K}, \mathrm{n}=6$ ). This indicated that P2X7R could be activated by high concentrations of ATP. Interestingly, we found that $20 \mu \mathrm{M}$ PPADS could partially inhibit the current induced by $1 \mathrm{mM}$ ATP (Supplementary Figure S3A, S3C), but had no effect on the current evoked by $5 \mathrm{mM}$ ATP (Supplementary Figure $\underline{\mathrm{S} 3 \mathrm{~B}}, \underline{\mathrm{S} 3 \mathrm{D}}$ ), which indicated that PPADS might have limited inhibitory effect on the activity of P2X7R. In addition, $\mathrm{P} 2 \mathrm{X} 7 \mathrm{R}$ was reported to be sensitive to divalent cations. ${ }^{34}$ Our results also showed that in the low divalent cationic external solution, the inward current induced by $5 \mathrm{mM}$ ATP was greater than that of the normal external solution (Figure $3 \mathrm{~F}$ and $\mathrm{L}$ ), which confirmed the presence of P2X7R in mouse peritoneal mast cells. Furthermore, the presence of P2X7R was further confirmed by immunofluorescence (Figure 3M-O). Taken together, our results illustrated that P2X1R, P2X3R, P2X4R and P2X7R were expressed in mouse peritoneal mast cells and were involved in the activation induced by extracellular ATP.

\section{Activation of P2X7R in Mouse-Derived Mast Cells Induced Cytokines Synthesis}

Degranulation is one of important indicators of mast cell activation. Consistent with the research of Wareham et $\mathrm{al}^{6}$, our results showed that there is no detectable histamine release at lower concentrations of ATP, such as 1 $\mu \mathrm{M}$ and $100 \mu \mathrm{M}$; however, histamine released from mouse peritoneal mast cells was significantly increased at higher concentrations of ATP (Figure 4A). In addition to histamine, mast cells are effective producers of inflammatory cytokines in response to various stimuli. The regulation of extracellular ATP on cytokine synthesis in mast cells remains unclear. Therefore, we detected the synthesis of a series of mediators such as IL-6, IL-1 $\beta$, CCL2 and CCL3. The mouse peritoneal mast cells were too few to be detected, so we used P815 cells instead. P815 cells also expressed P2X1R, P2X3R, P2X4R, and P2X7R (Supplementary Figure S4, Figure 4B). Figure $4 \mathrm{C}-\mathrm{G}$ showed the regulation of mediator synthesis was also related to ATP concentration. There was no significant change in the expression of cytokines in P815 cells stimulated with low concentrations of ATP ( $\mathrm{PH}$ was 7.32, adjusted by $\mathrm{NaOH}$ ) (Figure 4C-E). ATP with high concentrations (PH was 7.32, adjusted by $\mathrm{NaOH}$ ) could significantly up-regulate the expression of cytokines, including IL- $1 \beta$ and CCL3 (Figure 4F and G). AZ10606120, a specific P2X7R antagonist ( $5 \mu \mathrm{M}$, pre-incubation for 5 minutes), almost completely blocked the upregulation of IL-1 $\beta$ and CCL3 induced by $5 \mathrm{mM}$ ATP (Figure $4 \mathrm{H}$ ). Therefore, we believed that P2X7R in mast cells could mediate mast cells degranulation and de novo synthesis of inflammatory factors such as IL-1 $\beta$ and CCL3.

\section{High Concentrations of ATP Induced Inflammation Pain by Activating P2X7R in Mast Cells}

Activation of P2X7R in mast cells modulates the synthesis of inflammatory mediators that may further cause pain through neuro-immune interactions. We assumed that mast cells and $\mathrm{P} 2 \mathrm{X} 7 \mathrm{R}$ promoted the inflammatory 
A

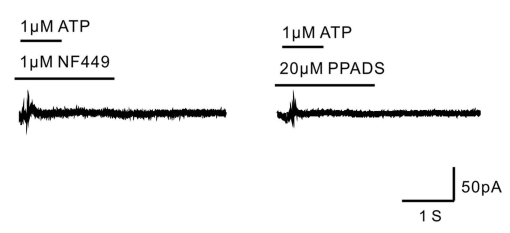

D

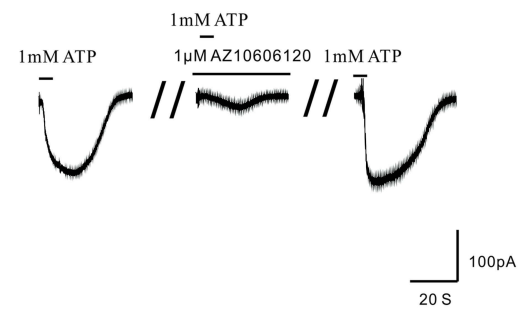

G

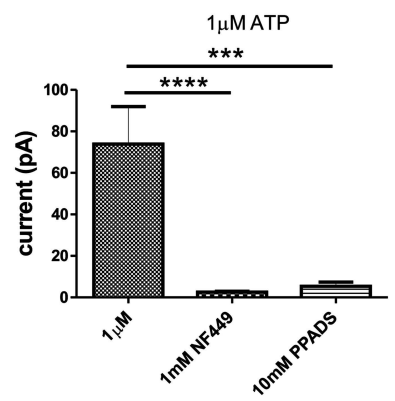

J

M
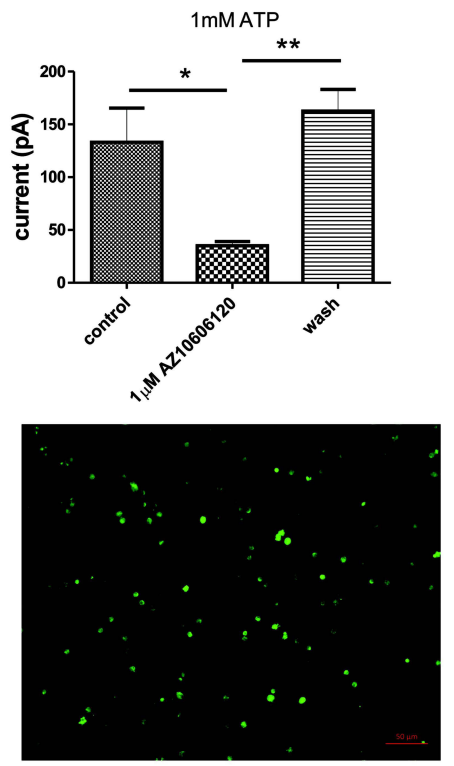

B

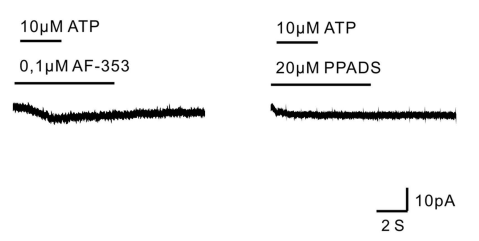

E

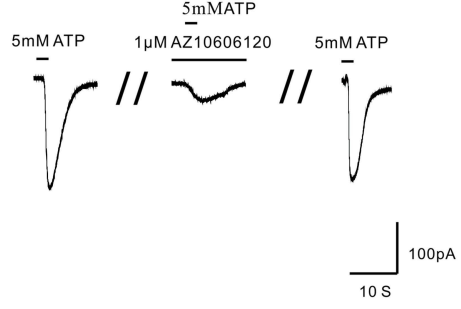

H

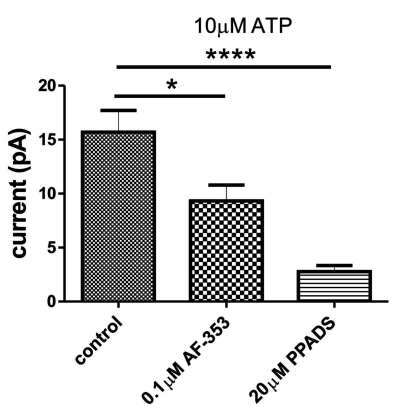

K

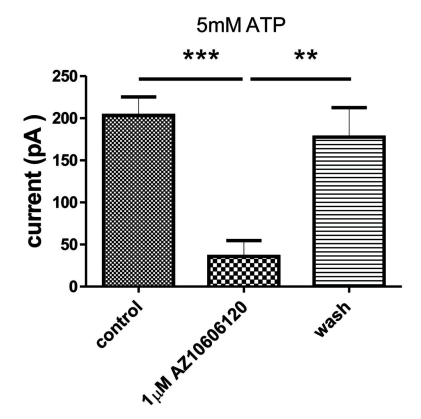

$\mathbf{N}$

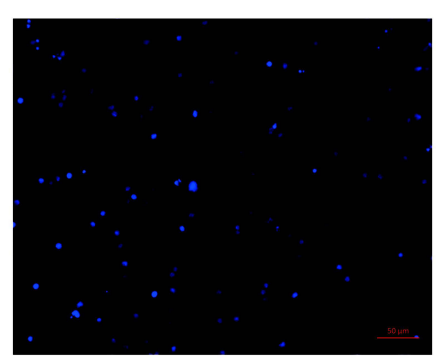

C

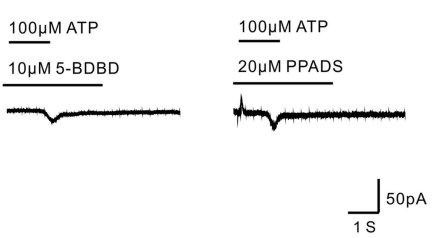

$\mathbf{F}$ - - normal livalent cation

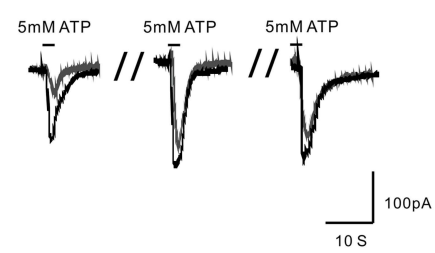

I

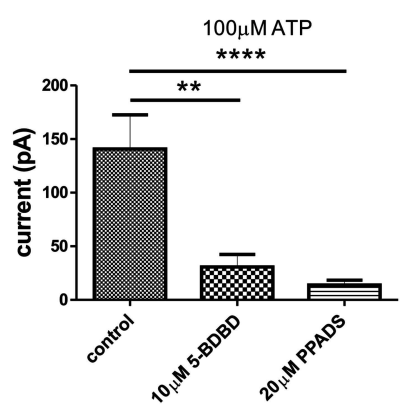

L

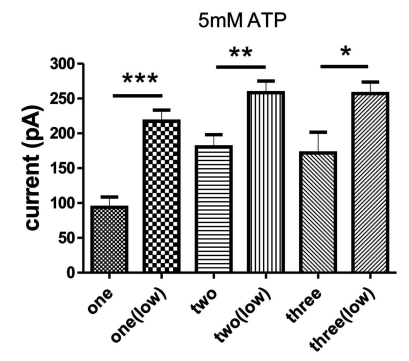

0

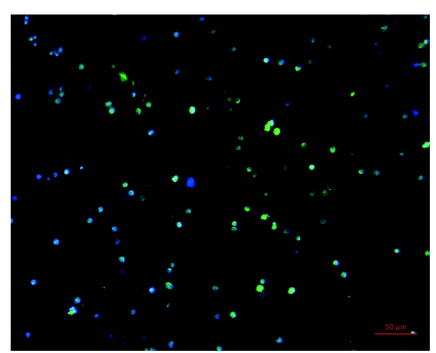

Figure 3 The effects of specific blockers on the currents evoked by extracellular ATP. (A) Cell with $20 \mu$ M PPADS or I $\mu$ M NF449 hardly evoke current by I $\mu$ M ATP treatment. (B) Current evoked by $10 \mu$ M ATP could be blocked by $20 \mu$ M PPADS or $0.1 \mu$ M AF-353. (C) The current induced by $100 \mu$ M ATP could be inhibited by $20 \mu M$ PPADS or $10 \mu M$ 5-BDBD. (D) The current induced by I mM ATP could be blocked by I $\mu$ M AZ10606I20. (E) I $\mu$ M AZI0606I20 could reduce the current evoked by 5 mM ATP. (F) 5 mM ATP could evoke greater inward current in the external solution with low divalent cation. (G) The current amplitude induced by I $\mu$ M ATP could be inhibited by PPADS or NF449 (****p $<0.000$ I, control vs $20 \mu$ M PPADS, $n=9, * * * p<0.001$, control vs I $\mu$ M NF449, $n=13$, one-way ANOVA analysis followed by Dunnett's multiple comparisons test). (H) The current amplitude evoked by $10 \mu$ M ATP was blocked by PPADS or AF-353 (***** $p<0.000$ I, control vs $20 \mu M$ PPADS, $n=9, * p<0.05$, control vs $0.1 \mu \mathrm{M}$ AF-353, $\mathrm{n}=10$, one-way ANOVA analysis followed by Dunnett's multiple comparisons test). (I) PPADS or 5-BDBD could inhibit the current amplitude evoked by $100 \mu$ M ATP (**p < 0.01, control vs $20 \mu$ M PPADS, $n=13$, ***** $p<0.0001$, control vs $10 \mu M$ 5-BDBD, $n=10$, one-way ANOVA analysis followed by Dunnett's multiple comparisons test). (J) The current amplitude evoked by I mM ATP was blocked by AZI0606I 20 ( ${ }^{*} p<0.05$, control vs I $\mu$ M AZI0606I20, $\mathrm{n}=5$, paired Student's $t$-test). (K) The current amplitude evoked by 5 mM ATP could also be blocked by AZI 0606120 (***p < 0.00I, control vs I $\mu$ M AZ I0606 I20, $n=6$, paired Student's $t$-test). (L) The current amplitude induced by $5 \mathrm{mM}$ ATP in the external solution with low divalent cation $(n=8)$ was greater than that in the normal external solution $(n=13)$. $(\mathbf{M}-\mathbf{O})$ Immunofluorescence staining showed P2X7R (M, green) in mouse peritoneal mast cells, and the nucleus was stained with DAPI (N, blue) (Scale bar is $50 \mu \mathrm{m})$. 
A

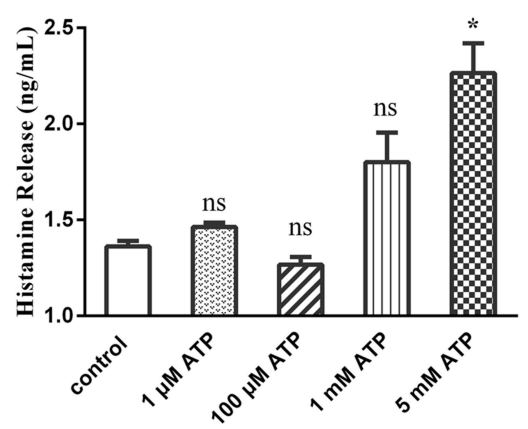

C

E

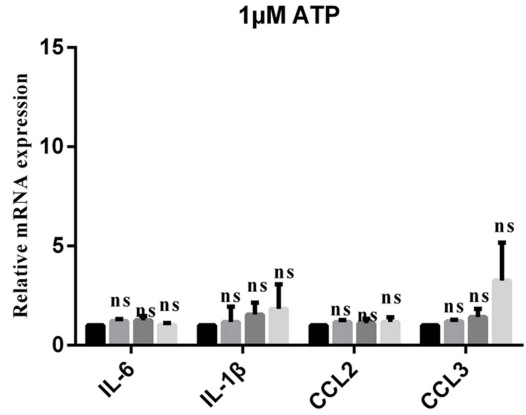

$100 \mu \mathrm{M}$ ATP

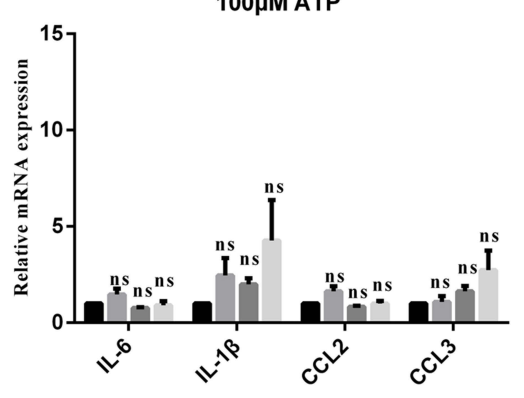

G

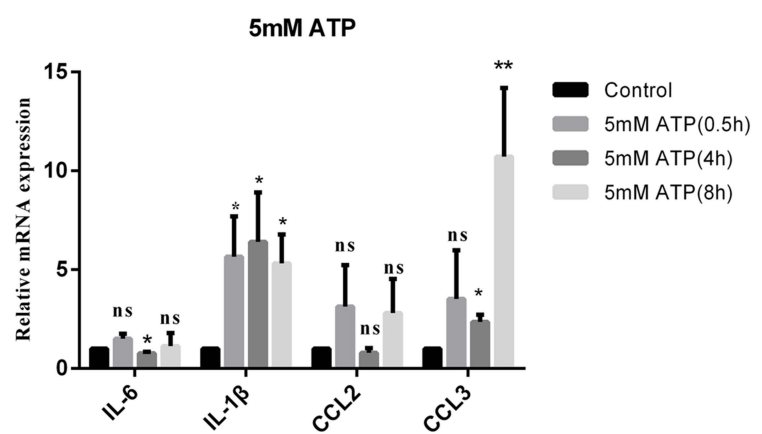

B

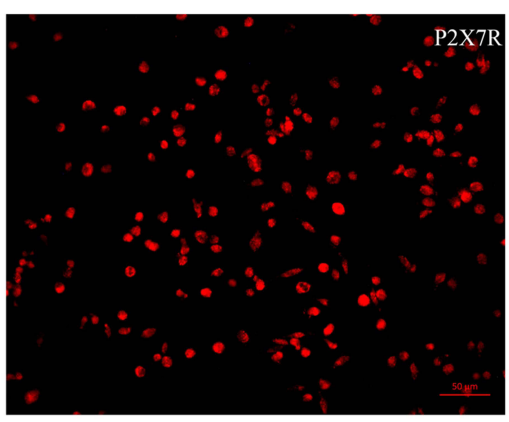

D

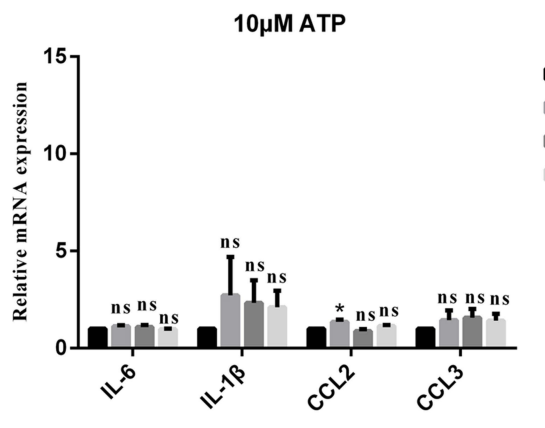

F

Control

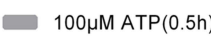

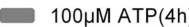

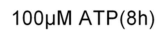

H

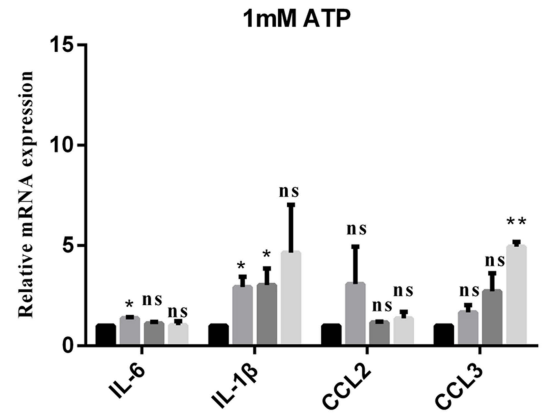

Control

1mM ATP $(0.5 \mathrm{~h})$

$1 \mathrm{mM}$ ATP $(4 \mathrm{~h})$

$1 \mathrm{mM}$ ATP(8h)

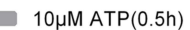

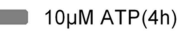

$10 \mu M$ ATP(8h)

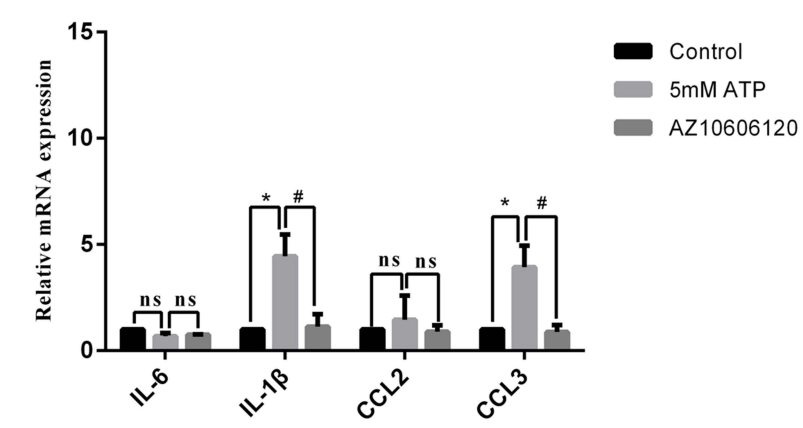

Figure 4 Effects of extracellular ATP at different concentrations on the synthesis and release of cytokines in mast cells. (A) High concentrations of ATP induced significantly increased histamine release from mouse peritoneal mast cells $\left({ }^{*} p<0.05\right.$, control vs $5 \mathrm{mM}$ ATP, one-way ANOVA analysis followed by Dunnett's multiple comparisons test). (B) Immunofluorescence staining exhibited P2X7R (red) in P8I5 cells, scale bar was $50 \mu \mathrm{M}$. (C-E) There was no significant changes in the expression of IL-6, IL-I $\beta$, CCL2 and CCL3 in P8I5 cells induced by I $\mu$ M ATP, $10 \mu$ M ATP or $100 \mu$ ATP, respectively. (F) The expression of IL-6, IL-I $\beta$ and CCL3 was up-regulated induced by I mM ATP in P8I 5 cells (*p< 0.05 , **p $<0.01$, control vs I mM ATP, one-way ANOVA analysis followed by Dunn's multiple comparisons test). (G) The expression of IL-I $\beta$ and CCL3 was up-regulated induced by $5 \mathrm{mM}$ ATP in P8I 5 cells ( ${ }^{*} p<0.05$, ${ }^{*} p<0.01$, control vs $5 \mathrm{mM}$ ATP, one-way ANOVA analysis followed by Dunn's multiple comparisons test). (H) The up-regulation of IL-I $\beta$ and CCL3 expression caused by $5 \mathrm{mM}$ ATP in P8I 5 cells was blocked by specific P2X7R antagonist AZI0606I20. ( ${ }^{*} p<0.05$, control vs 5 mM ATP; ${ }^{p}<0.05,5$ mM ATP vs $5 \mu$ M AZ10606I20, one-way ANOVA analysis followed by Tukey's multiple comparisons test). 
pain induced by high concentrations of ATP. In order to prove this hypothesis, we utilized the mast cell-deficient Kit (W-sh) Sash mutant mice and the P2X7R antagonist, AZ10606120. First, results showed that high concentrations of ATP $(100 \mathrm{mM}, 10 \mu \mathrm{L}$, PH was 7.32, Intradermal injection) could induce inflammation pain, including paw swelling (Figure 5A), inflammatory cells infiltration (Figure 5B), increased paw thickness (Figure 5C), mast cells degranulation (Figure 5D), and mechanical hyperalgesia (Figure 5E). As we expected, mast cell-deficient mice could alleviate ATP-induced inflammation pain (Figure 5A-E). As shown in Figures 5F, $1 \mathrm{~h}$ after ATP administration, the mRNA expression levels of IL-6, IL$1 \beta$, CCL2 and CCL3 in C57/BL mice were significantly up-regulated. Compared with C57/BL mice, Sash mice alleviated the upregulation of IL-1 $\beta$ and CCL3 (Figure 5F). At the same time, we also investigated the role of P2X7R in ATP-induced inflammatory pain. Results showed that AZ10606120 (2 mg/kg, ip, preadministration $1 \mathrm{~h}$ ) could significantly reduce the mechanical hypersensitivity (Figure $5 \mathrm{H}$ ). As shown in Figure 5G, the infiltration of mast cells expressing P2X7R was significantly increased, which could be inhibited by Z10606120. Correspondingly, the upregulation of inflammatory factors such as IL-6 and CCL3 could also be blocked by AZ10606120 (Figure 5I).

\section{Salicylic Acid and Aspirin Inhibited the Activation of P2X7R in Mast Cells}

$\mathrm{P} 2 \mathrm{X} 7 \mathrm{R}$ is an appealing target for anti-inflammatory therapy, so we used P2X7R as a target to screen for several antiinflammatory monomers that can inhibit its activity. Results showed that Matrine, Higenamine, Dictamnine, Prim$O$-glucosylcimifugin, Liquiritin, Menthol, Ferulic Acid, 3-Hydroxy-4-methoxycinnamic acid, Isoginkgetin, Vanillic acid, Luteolin, Isoliquiritigenin or Aloeemodin had no inhibitory effect on the current evoked by $5 \mathrm{mM}$ ATP (Supplementary Table 1). Interestingly, as shown in Figure 6A, we found that SA and ASA could inhibit the inward current induced by $5 \mathrm{mM}$ ATP. Compared with the first ATP-induced current amplitude, $300 \mu \mathrm{M}, 500 \mu \mathrm{M}$, or 1 mM SA slightly inhibited the second ATP-induced current amplitude (Figure 6B-D, $n=21, n=14$, and $n=16$, respectively). Notably, the current induced by $5 \mathrm{mM}$ ATP had a "run-up" tendency, indicating that the current growth rate should be analyzed. Data showed that the current growth rate induced by $5 \mathrm{mM}$ ATP was significantly inhibited by
SA as Figure $6 \mathrm{E}$ shown. $500 \mu \mathrm{M}$ or $1 \mathrm{mM}$ ASA could also inhibit the current amplitude induced by $5 \mathrm{mM}$ ATP (Figure $6 \mathrm{~F}-\mathrm{H}, \mathrm{n}=8$ and $\mathrm{n}=20$ respectively). The current growth rate was significantly inhibited by $300 \mu \mathrm{M}, 500$ $\mu \mathrm{M}$ or $1 \mathrm{mM}$ ASA (Figure 6I). The results of intracellular $\mathrm{Ca}^{2+}$ concentration assay showed that $300 \mu \mathrm{m}$ SA or $1 \mathrm{mM}$ ASA could also inhibit calcium influx induced by $5 \mathrm{mM}$ ATP (Supplementary Figure S5). To further clarify the relationship between SA or ASA and P2X7R, the P2X7R agonist BzATP was used. Results showed that $300 \mu \mathrm{M}$ SA $(n=18)$ or $300 \mu \mathrm{M}$ ASA $(n=7)$ significantly inhibited the current growth rate (Figure $6 \mathrm{~J}$ ) and the calcium influx (Supplementary Figure S6) evoked by BzATP. In addition, we also found that the up-regulation of P2X7R expression could also be blocked by $500 \mu \mathrm{M}$ SA or $1 \mathrm{mM}$ ASA (Figure 6K). As we expected, $500 \mu \mathrm{M} \mathrm{SA}$ or $1 \mathrm{mM}$ ASA also inhibited the up-regulation of IL-1 $\beta$ and CCL3 expression (Figure 6L), and the release of IL-1 $\beta$ and CCL3 was inhibited slightly by SA or ASA (Supplementary Figure S7).

\section{P2X7R in Mast Cells is a Potential Target for Salicylic Acid and Aspirin Analgesia}

The previous results indicated that SA or ASA could inhibit the activity of P2X7R in mast cells, we speculated that SA or ASA might relieve inflammation pain through P2X7R. Therefore, we explored the effects of SA or ASA on the inflammation pain induced by high concentrations of ATP. Results showed that SA $(50 \mathrm{mg} / \mathrm{kg}$, ig, pretreated 1h) or ASA ( $50 \mathrm{mg} / \mathrm{kg}$, ig, pretreated $1 \mathrm{~h}$ ) could relieve the mechanical hypersensitivity induced by $100 \mathrm{mM}$ ATP (Figure 7B). As shown in Figure 7A, the infiltration of mast cells expressing P2X7R was significantly increased, which could be inhibited by SA or ASA. In addition, the upregulation of inflammatory factors expression including IL-6, IL-1 $\beta$ and CCL3 could also be blocked by SA or ASA (Figure 7C).

\section{GDP Binding Region is Critical for the Combination of Salicylic Acid and Aspirin with P2X7R}

Our results suggested that the analgesic effects of SA and ASA also be achieved by inhibiting P2X7R. Next, we wondered if SA or ASA had a direct effect on P2X7R. To uncover this, we used Discovery Studio software to perform molecular docking analysis on the interaction between SA or ASA and P2X7R (Figure 8). Results showed that SA (Figure $8 \mathrm{G}-\mathrm{L}$ ) and its derivative ASA 
A
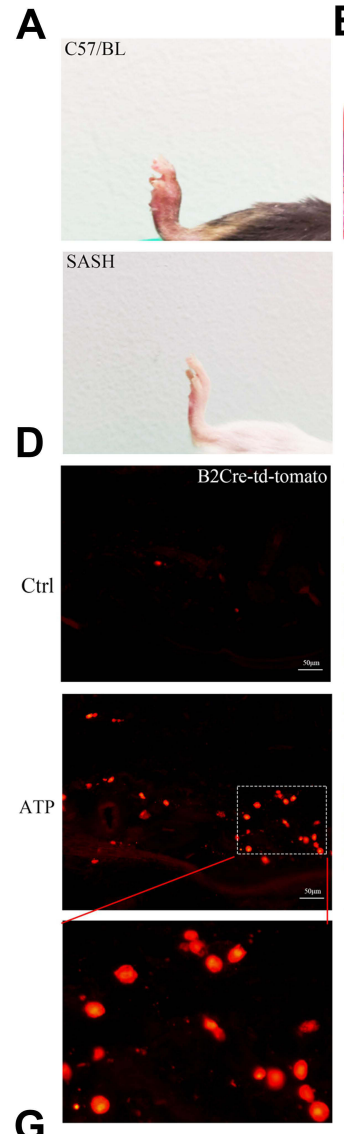

G
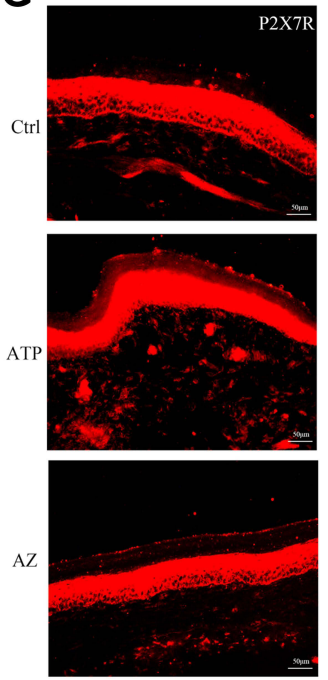

B
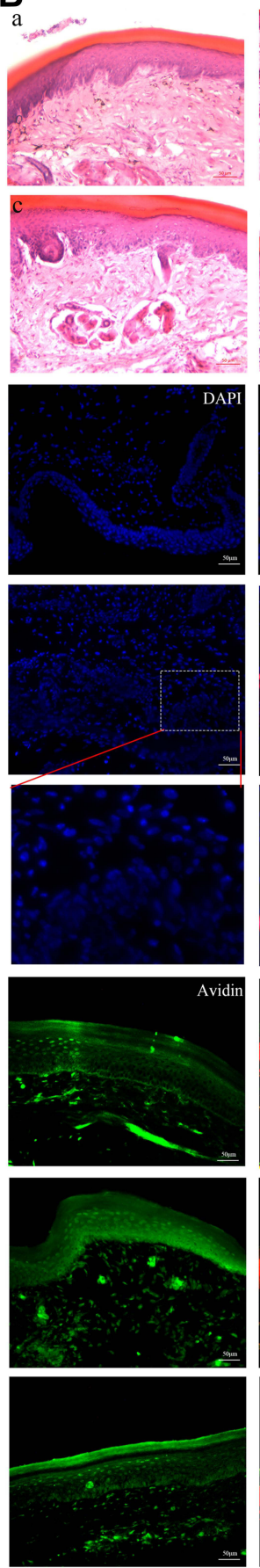

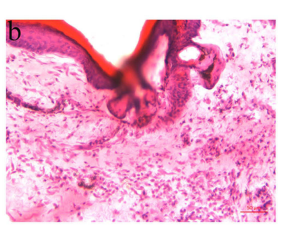

\section{d}
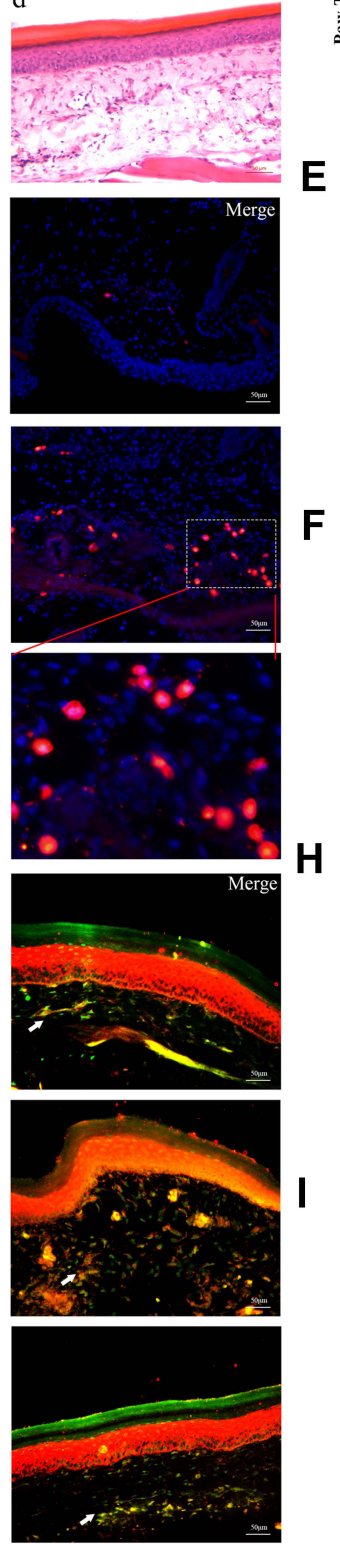

E

$F$

H
C
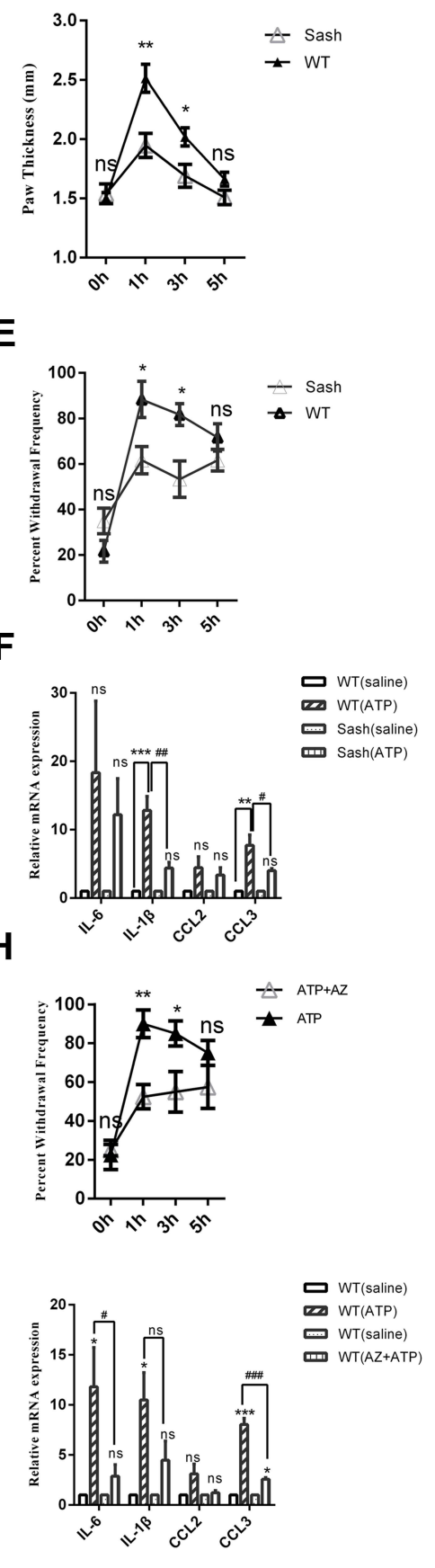

Figure 5 Mast cell deficient and AZI0606/20 alleviated high concentrations of ATP-induced inflammation pain. (A) Compared with C57/BL mice, Sash mice alleviated the paw swelling. (B) Compared with the C57/BL mice, the infiltration of inflammatory cells in Sash mice was significantly reduced. (a-b, HE staining of saline and ATP groups in C57/BL mice; c-d, HE staining of saline and ATP groups in Sash mice, 250X). (C) Compared with C57BL mice, Sash mice significantly reduced paw thickening ( ${ }^{\circ} p<0.05$, ** $^{*}<0.0 \mathrm{I}$, WT group vs Sash group, $\mathrm{n}=8$ and 6 respectively). (D) High concentrations of ATP induced mast cells degranulation (The construction of Mrgprb2-Cre tdT +mice was to integrate the fluorescent protein of Td/Tomato into the promoter of MrgprB2, red represented mast cells, and the small red granules around mast cells represented degranulation). (E) Sash mice alleviated the mechanical hyperalgesia induced by high concentrations of ATP $(* p<0.05$, WT group vs Sash group, $n=8$ and 6 respectively). (F) Mast cell deficient attenuated the upregulation of IL-I $\beta$ and CCL3 $\left({ }^{* *} p<0.0\right.$ I, ${ }^{* * *} p<0.00$ I, saline group vs ATP group, ${ }^{\#} p<0.05$, ${ }^{\# \#} p<0.0$ I, WT (ATP) group vs Sash (ATP) group). (G) The infiltration of mast cells expressing P2X7R was significantly increased, which could be inhibited by ZI0606I20. (H) AZI0606I20 significantly relieved the mechanical hyperalgesia. ( ${ }^{*} p<0.05$, ${ }^{* *} p<0.0$ I, ATP group vs ATP+AZI 0606 I 20 group). (I) AZI0606I20 attenuated the up-regulation of IL-6 and CCL3 $\left(* p<0.05,{ }^{*} * * p<0.001\right.$, saline group vs ATP group, ${ }^{\#} p<0.05,{ }_{p}<0.00$ I, WT (ATP) group vs WT (AZ+ATP) group). (Statistical analysis of the results was performed one-way ANOVA analysis followed by Dunnett's multiple comparisons test or Tukey's multiple comparisons test). 
A

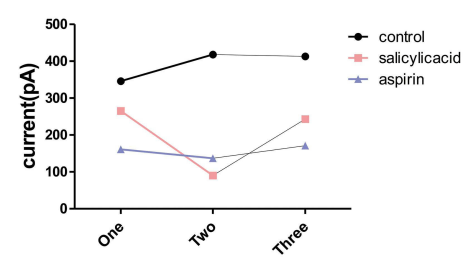

D

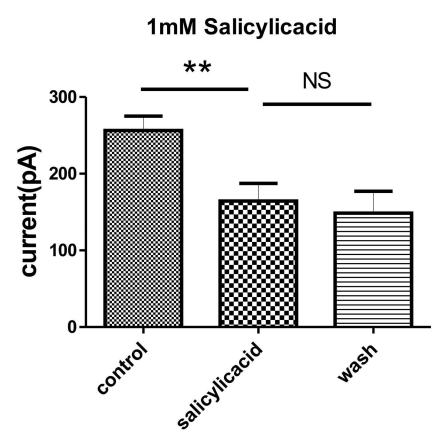

G
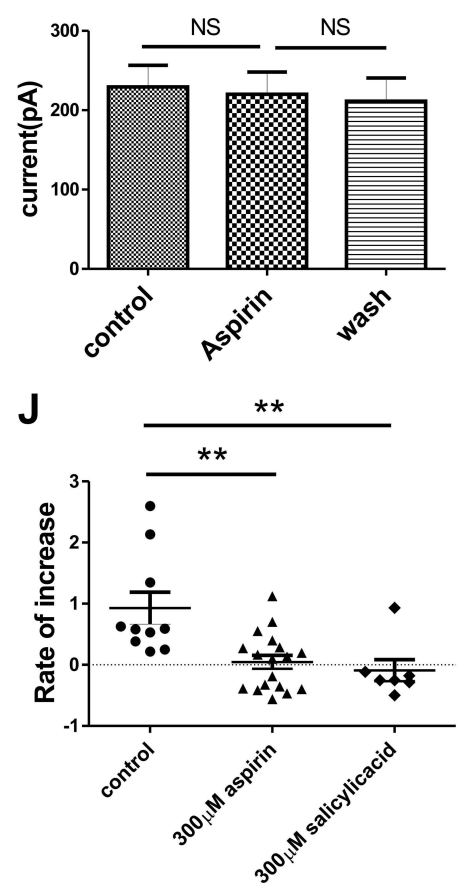

B

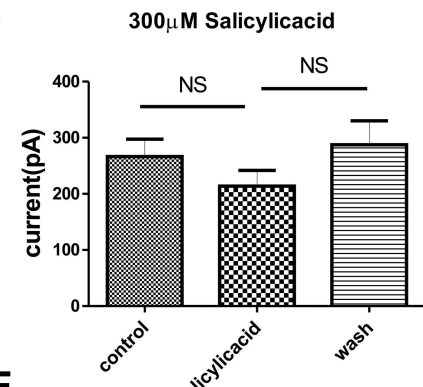

E

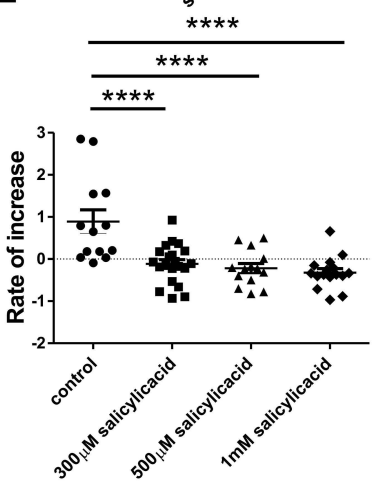

H
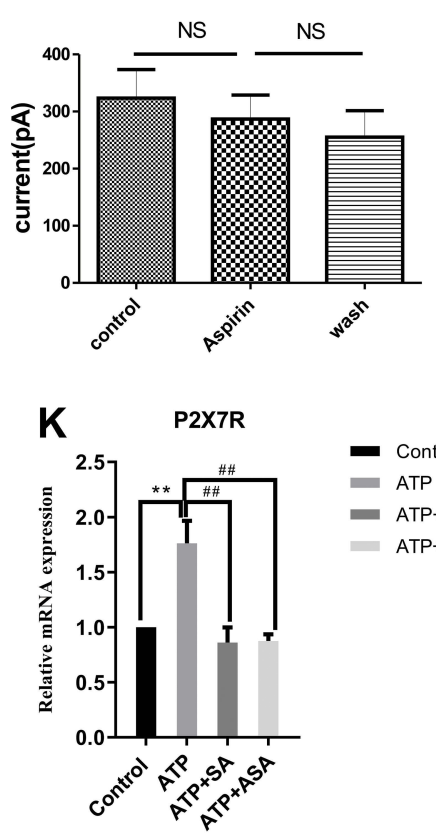

C

$500 \mu \mathrm{M}$ Salicylicacid

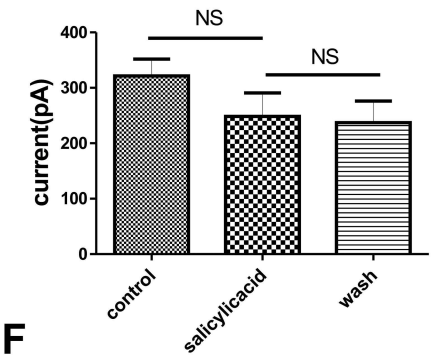

F

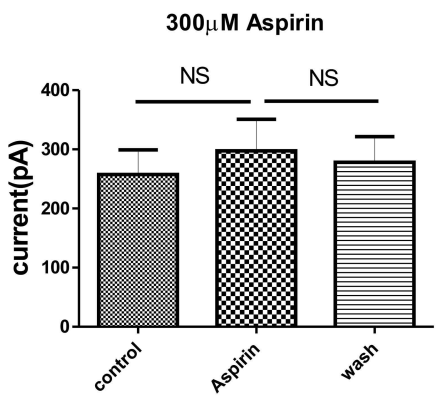

I

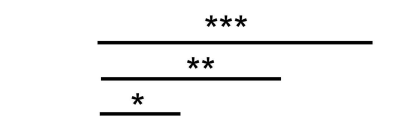

$\mathbf{L}$
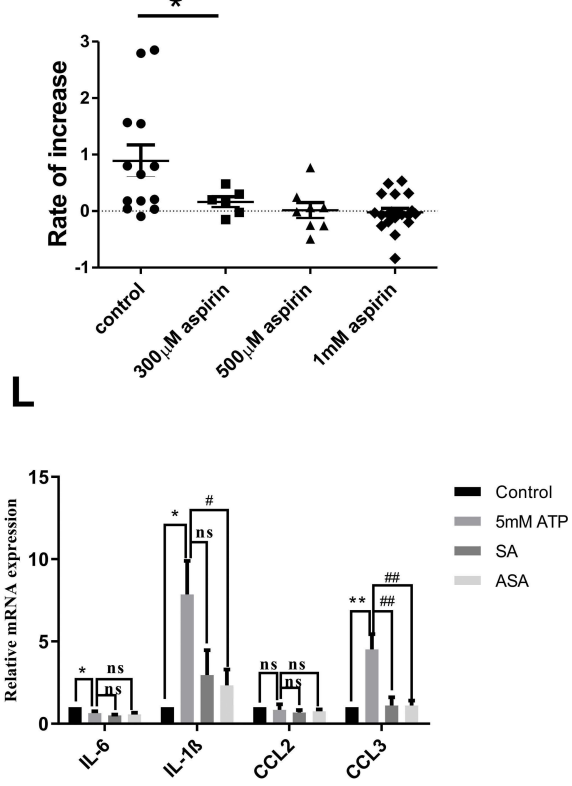

Figure 6 The effects of SA and ASA on the activation of P2X7R in mast cells. (A) Schematic diagram of the effect of SA and ASA on 5 mM ATP-induced current. (B) Compared with the first ATP-induced current amplitude, $300 \mu \mathrm{M}$ SA had a slight inhibitory effect on the second ATP-induced current amplitude. (C) Compared with the first ATP-induced current amplitude, $500 \mu \mathrm{M}$ SA slightly inhibited the second ATP-induced current amplitude. (D) Compared with the first ATP-induced current amplitude, I $\mathrm{mM}$ SA significantly inhibited the second ATP-induced current amplitude (**p<0.0I, control vs I mM SA). (E) The current growth rate was significantly inhibited by different concentrations of SA (****p<0.000I, control vs $300 \mu \mathrm{M} \mathrm{SA}, 500 \mu \mathrm{M}$ SA or I mM SA). (F-H) Compared with the first ATP-induced current amplitude, $500 \mu \mathrm{M}$ (G) or I mM ASA (H) slightly inhibited the second ATP-induced current amplitude. (I) The current growth rate was significantly inhibited by different concentrations of ASA $\left({ }^{*} p<0.05\right.$, control vs $300 \mu \mathrm{M}$ ASA; **p<0.0I, control vs $500 \mu \mathrm{M}$ ASA; $* * * p<0.001$, control vs I mM ASA). (J) The current growth rate evoked by BzATP was significantly inhibited by $300 \mu \mathrm{M}$ SA or $300 \mu \mathrm{M}$ ASA (**p<0.0I, control vs $300 \mu \mathrm{M}$ SA or $300 \mu \mathrm{M}$ ASA). (K) The up-regulation of P2X7R expression induced by $5 \mathrm{mM}$ ATP was blocked by $500 \mu \mathrm{M}$ SA or I mM ASA (**p<0.0I, control vs ATP, ${ }^{*} p<0.01$, ATP vs ATP+SA or ATP+ASA). (L) SA or ASA attenuated the up-regulation of IL-I $\beta$ and CCL3 expression $(* p<0.05$, ${ }^{* *} p<0.01$, control vs ATP, ${ }^{\#} p<0.05$, ${ }^{\#} p<0.0$ I, ATP vs SA or ASA). (Statistical analysis of the results was performed one-way ANOVA analysis followed by Dunnett's multiple comparisons test or Tukey's multiple comparisons test). 
A
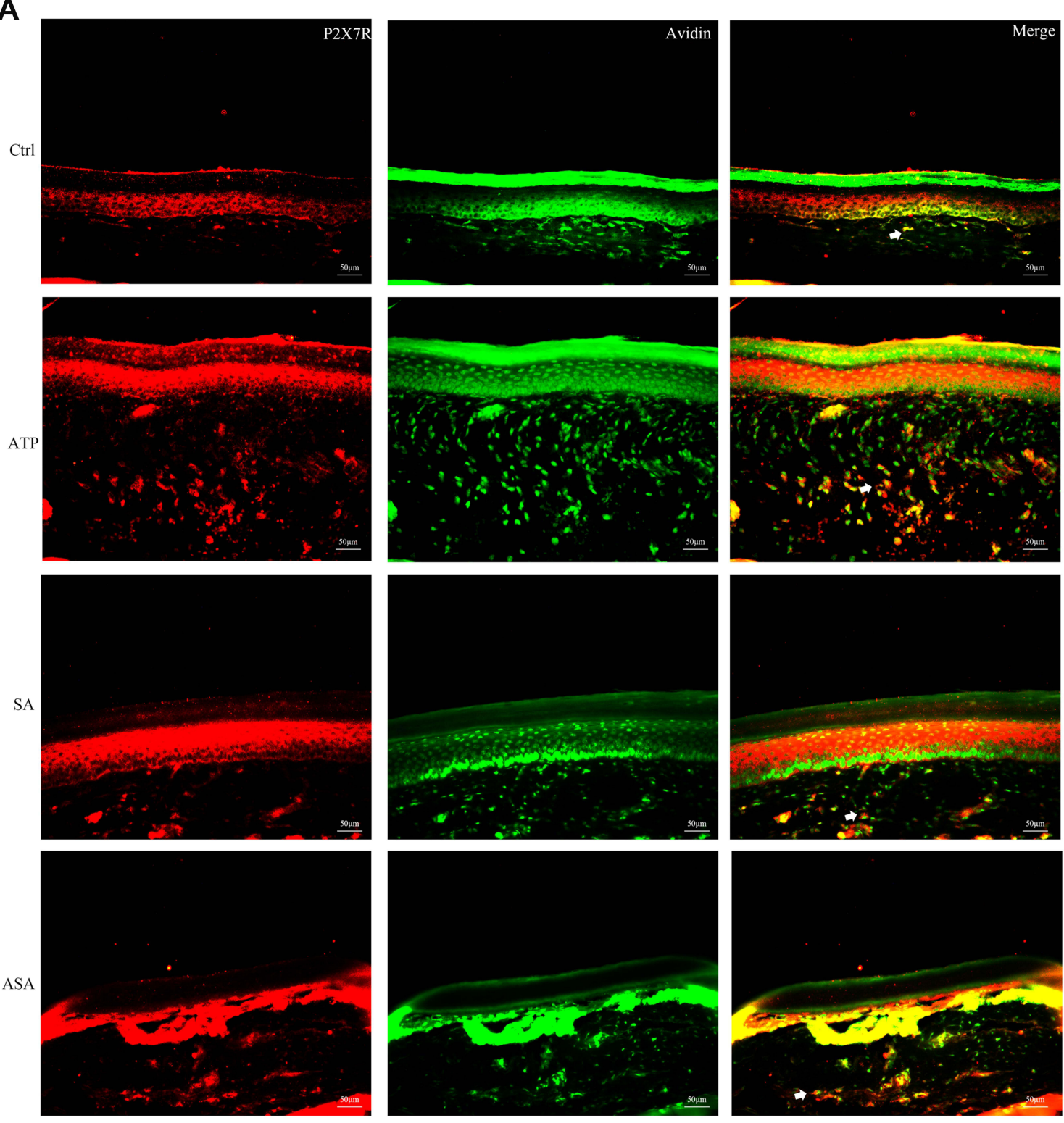

B

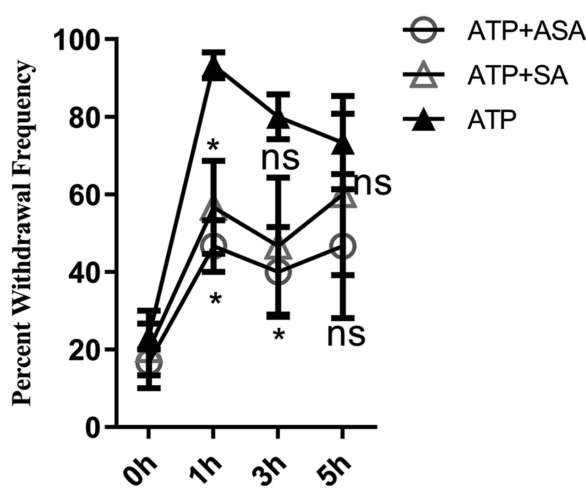

C

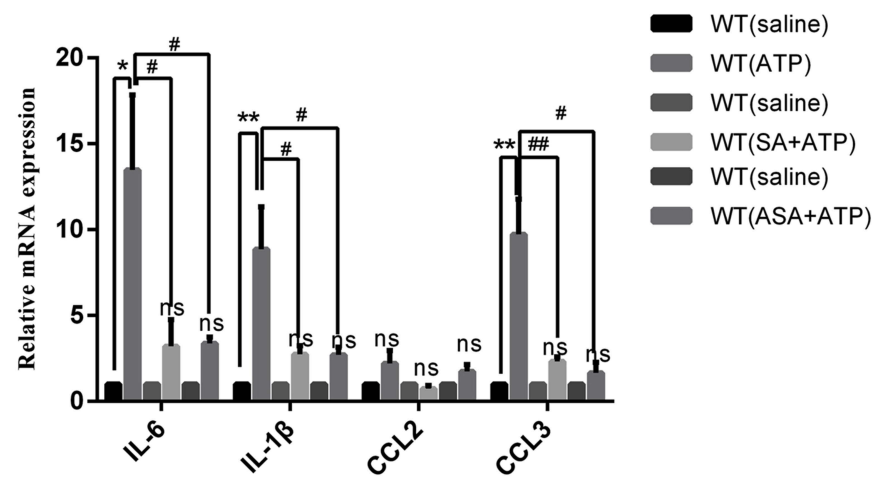

Figure 7 The effects of SA or ASA on the inflammation pain through P2X7R. (A) The infiltration of mast cells expressing P2X7R was significantly increased induced by high concentrations of ATP, which could be inhibited by SA or ASA. (B) SA or ASA relieve the mechanical hypersensitivity induced by high concentrations of ATP $\left({ }^{*}<<0.05\right.$, ATP vs ATP+SA or ATP+ASA). (C) SA or ASA attenuated the up-regulation of inflammatory factors expression $\left({ }^{*} p<0.05, * * p<0.0\right.$, saline group vs ATP group, ${ }^{*} p<0.05$, ${ }^{*} p<$ 0.0I, WT (ATP) group vs WT (SA+ATP) or WT (ASA+ATP) group). (Statistical analysis of the results was performed one-way ANOVA analysis followed by Dunnett's multiple comparisons test or Tukey's multiple comparisons test). 
A

C
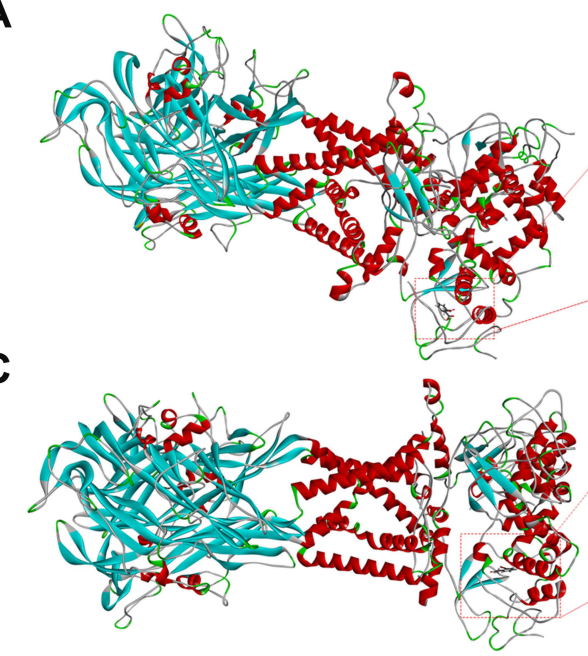

E

$\mathbf{G}$
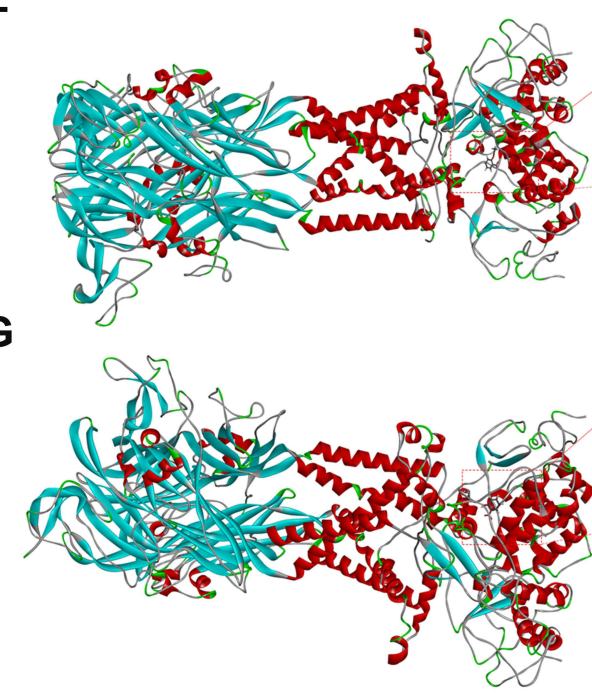

I

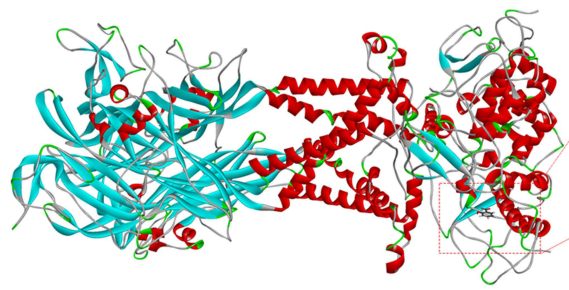

K

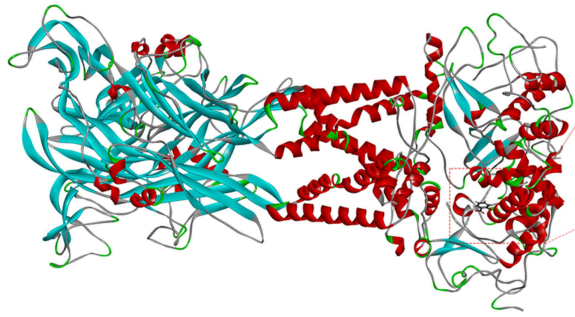

A:GDP binding ligand

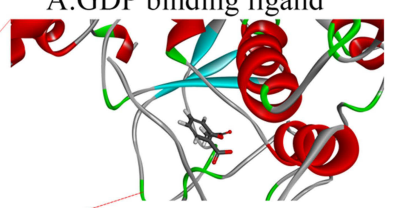

B: GDP binding ligand

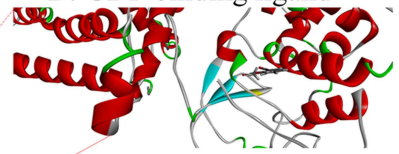

C: GDP binding ligand

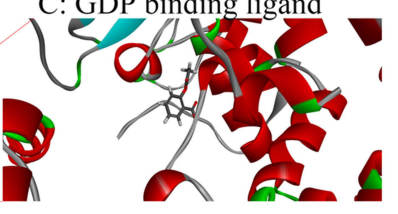

A:GDP binding ligand

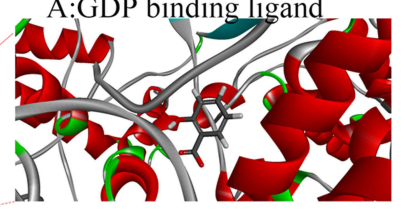

B

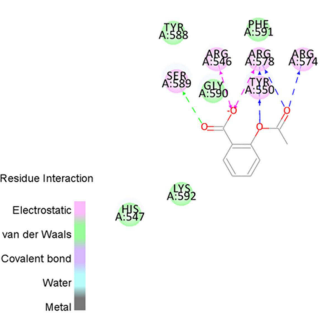

D

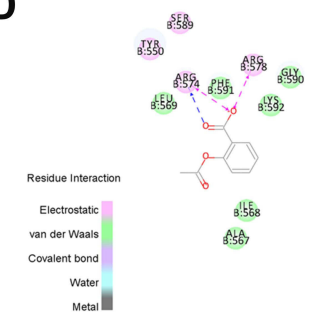

F

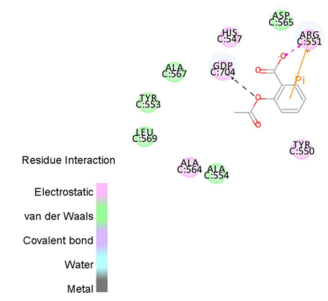

H
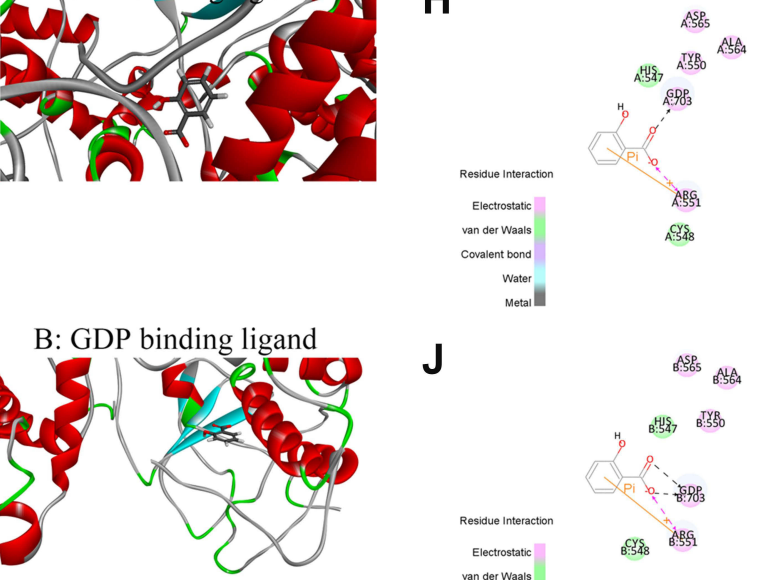

J

$$
\text { a.s50 }
$$

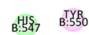

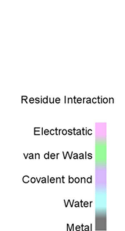

C: GDP binding ligand

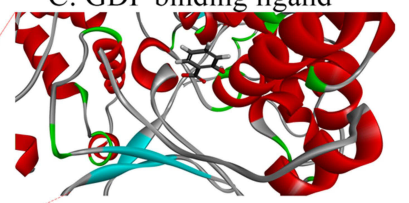

L

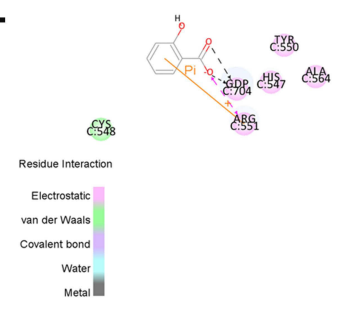

Figure 8 Molecular docking map of compounds with P2X7R. (A and B) Docking result of ASA with the (A) GDP703 ligand of P2X7R. (C and D) Docking result of ASA with the (B) GDP703 ligand of P2X7R. (E and F) Docking result of ASA with the (C) GDP704 ligand of P2X7R. (G and H) Docking result of SA with the (A) GDP703 ligand of P2X7R. (I and J) Docking result of SA with the (B) GDP703 ligand of P2X7R. (K and L) Docking result of SA with the (C) GDP704 ligand of P2X7R. 
(Figure 8A-F) had affinity with the GDP-binding region of P2X7R, including A: GDP 703, B: GDP703 and C: GDP704 ligands. Among them, ASA had the highest affinity with A: GDP 703 ligand as Figure 8A and B showed. The $-\mathrm{COOH}$ of aspirin formed two Electrostatic-bonds with Arg546 (R546) and Arg578 (R578) of A: GDP 703 ligand, and a van der Waals-bond with Ser589 (S589). Combined with these results, we considered that SA and ASA could inhibit P2X7R activation by directly binding the receptor, thereby reducing inflammatory pain.

\section{Discussion}

P2X7R belongs to the family of ATP-sensitive ionotropic $\mathrm{P} 2 \mathrm{X}$ receptors that are composed of seven homomeric receptor subtypes. $\mathrm{P} 2 \mathrm{X} 7 \mathrm{R}$ is an unusual member of the $\mathrm{P} 2 \mathrm{X}$ receptor superfamily since it is activated by high concentrations of ATP. ${ }^{35}$ P2X7R mediates NLRP3 inflammasome activation, cytokine and chemokine release, $\mathrm{T}$ lymphocyte survival and differentiation, transcription factor activation, and cell death. ${ }^{36}$ Activation $\mathrm{P} 2 \mathrm{X} 7 \mathrm{R}$ promotes release of pro-inflammatory factors, such as IL-1 $\beta$, IL-6, CCL2, TNF $\alpha$, CCL3, and nitric oxide, suggesting that $\mathrm{P} 2 \mathrm{X} 7 \mathrm{R}$ is an obvious candidate to play a major and pivotal role in processes of inflammation and pain. ${ }^{37}$ Inhibition of P2X7R by Brilliant BlueG (BBG) or OxATP could alleviate the inflammatory pain induced by TRPA1 agonist mustard oil. ${ }^{38}$ In addition, the P2X7R antagonist OXATP also alleviates pain in arthritis induced by complete Freund's adjuvant (CFA), including a reduction of edema in the inflamed paw. ${ }^{39} \mathrm{P} 2 \mathrm{X} 7 \mathrm{R}$ in mast cells also has been proved to be crucial in inflammation diseases. ATP-P2X7R-mediated mast cell activation induces the recruitment of neutrophils by inflammatory cytokines, chemokines, and leukotrienes, thereby exacerbating intestinal inflammation. ${ }^{24}$ Preventive oral magnesium could ameliorate colitis by reducing the accumulation of P2X7R-expressing mast cells in the colon. $^{40}$ In addition to intestinal inflammation, studies have shown that ATP-driven mast cell activation by $\mathrm{P} 2 \mathrm{X} 7 \mathrm{R}$ is also a potential trigger for neuro-inflammation and pain sensitization in migraine. ${ }^{25}$ Until now, the relationship between P2X7R in mast cells and inflammatory pain has not been clarified. Therefore, in current study, we explored the effect of P2X7R in mast cells on inflammatory pain, and selected $\mathrm{P} 2 \mathrm{X} 7 \mathrm{R}$ as a target to screen for some anti-inflammatory monomers that inhibited its activity.
First of all, we found that several functional $\mathrm{P} 2 \mathrm{X}$ receptors were expressed in mouse peritoneal mast cells, including P2X1R, P2X3R, P2X4R, and P2X7R. The expression profile was similar to that of mouse bone marrow mast cells, LAD2 and human lung mast cells, which expressed P2X1R, P2X4R, and P2X7R. ${ }^{6}$ Extracellular ATP could induce calcium influx in mouse peritoneal mast cells in a concentration-dependent manner. Specific $\mathrm{P} 2 \mathrm{X}$ inhibitors results indicated that $\mathrm{P} 2 \mathrm{X} 1 \mathrm{R}, \mathrm{P} 2 \mathrm{X} 3 \mathrm{R}$, P2X4R and P2X7R were involved in the calcium influx induced by $1 \mu \mathrm{M}$ ATP, $10 \mu \mathrm{M}$ ATP, $100 \mu \mathrm{M}$ ATP and high concentrations of ATP such as $1 \mathrm{mM}$ and $5 \mathrm{mM}$, respectively. Notably, calcium influx could not be completely blocked by specific inhibitors, suggesting that other receptors were also involved. For example, in addition to P2X4R, P2Y2R can also be stimulated by ATP at a concentration of $100 \mu \mathrm{M}^{23}$ In addition, the inward currents induced by ATP in mouse peritoneal mast cells were concentration-dependent as well. Consistent with the previous studies, ${ }^{6}$ our results showed that P2X1R, P2X3R, $\mathrm{P} 2 \mathrm{X} 4 \mathrm{R}$ and P2X7R were involved in the currents induced by $1 \mu \mathrm{M}$ ATP, $10 \mu \mathrm{M}$ ATP, $100 \mu \mathrm{M}$ ATP and high concentrations of ATP, respectively. Furthermore, the presence of P2X7R was further confirmed by immunofluorescence. Taken together, we concluded that P2X1R, P2X3R, $\mathrm{P} 2 \mathrm{X} 4 \mathrm{R}$ and $\mathrm{P} 2 \mathrm{X} 7 \mathrm{R}$ were expressed in mouse peritoneal mast cells.

To investigate the role of P2X7R in mast cells, we explored the mediator release induced by ATP. The data showed that ATP with high concentrations could induce histamine release, which was consistent with previous report. $^{23}$ In addition to degranulation, the expression of IL-1 $\beta$ and CCL3 in P815 cells was up-regulated by $5 \mathrm{mM}$ ATP, which could be blocked by AZ10606120. These results suggested that $\mathrm{P} 2 \mathrm{X} 7 \mathrm{R}$ was involved in mast cells degranulation and the synthesis of inflammatory mediators. Neuron-immune crosstalk plays important roles in many inflammatory diseases, we hypothesize that activation of P2X7R in mast cells could indirectly induce peripheral pain, as shown in Figure 9. Histamine plays a critical role in neurogenic inflammation and pain transmission via specific receptors in a bidirectional manner. ${ }^{41}$ IL-1 $\beta$ can modulate neuronal activity directly, blocking IL1 signaling could alleviate inflammation pain. ${ }^{42}$ Furthermore, the roles of inflammatory chemokines could regulate synaptic transmission, especially CCL2/CCR2 and CCL3/CCR1 signaling. ${ }^{43}$ Consistent with this hypothesis, our results also showed that P2X7R in mast cells 


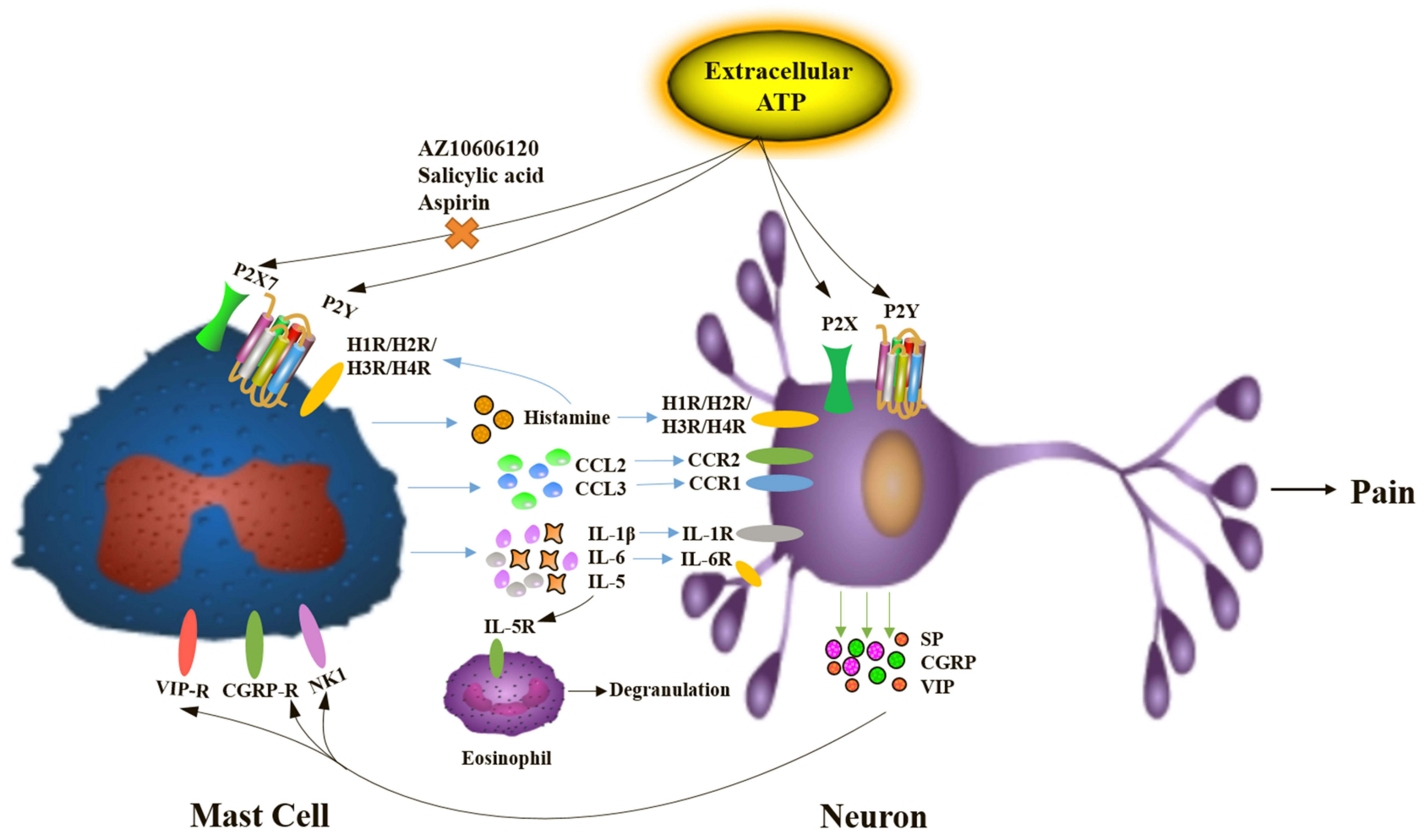

Figure 9 The mechanism of inflammation pain induced by extracellular ATP via neuron-immune crosstalk.

participated in the inflammation pain. As shown in Figure 5G, we found that P2X7R-expressing mast cells significantly increased in the inflammatory pain induced by high concentrations of ATP. AZ10606120 could alleviate this pain by inhibiting the infiltration of P2X7Rexpressing mast cells.

Pain is a serious global health issue and a huge clinical challenge without available effective treatment. Therefore, the discovery of novel therapeutic alternatives with superior effectiveness and minimal adverse effects would be beneficial. P2X7R is proposed as a new drug candidate for inflammatory disorders. Therefore, we used $\mathrm{P} 2 \mathrm{X} 7 \mathrm{R}$ as a target to screen for some anti-inflammatory monomers that could inhibit its activity. Interestingly, we found that SA and ASA could inhibit the inward current and calcium influx induced by ATP with high concentrations or P2X7R agonist BZATP. Meanwhile, SA and ASA also inhibited the up-regulation of P2X7R, IL- $1 \beta$ and CCL3 expression induced by high concentrations of ATP in vitro. Moreover, we also found that SA and ASA could alleviate the inflammatory pain induced by high concentrations of ATP in vivo, which was related to reducing the recruitment of mast cells expressing P2X7R. Molecular docking results showed that SA and ASA had affinity with the cytoplasmic GDP-binding region of P2X7R. Therefore, SA and ASA may inhibit the activity of P2X7R by binding the GDP-binding region, thereby alleviating inflammatory pain. The binding patterns and binding sites of SA and ASA on P2X7R need to be further verified.

\section{Conclusion}

In summary, we found that mouse-derived mast cells could be activated by extracellular ATP via P2X1, P2X3, P2X4, and $\mathrm{P} 2 \mathrm{X} 7$ receptors. Activation of $\mathrm{P} 2 \mathrm{X} 7 \mathrm{R}$ in mast cells played an important role in inflammatory pain by releasing inflammatory mediators. In addition, we also found that P2X7R might be a potential target for analgesics SA and ASA.

\section{Abbreviations}

ATP, adenosine-triphosphate; P2X7R, P2X7 receptor; IL$1 \beta$, interleukin-1 $\beta$; IL-6, interleukin-6; CCL2, C-C motif chemokine 2; CCL3, C-C motif chemokine 3; GDP, guanosine diphosphate; MrgprB2, MAS-related GPR member B2; SCF, stem cell growth factors; SA, salicylic acid; ASA, acetylsalicylic acid. 


\section{Acknowledgments}

The authors thank Prof. Xinzhong Dong in Johns Hopkins for kindly providing the Mast cell-deficient Kit (W-sh) "Sash" mutant mice and Mrgprb2-Cre tdT +mice. The authors thank Prof. Ye Yu in China Pharmaceutical University for kindly providing the $\mathrm{P} 2 \mathrm{X} 3 \mathrm{R}$ antagonist AF-353.

\section{Author Contributions}

All authors made a significant contribution to the work reported, whether that is in the conception, study design, execution, acquisition of data, analysis and interpretation, or in all these areas; took part in drafting, revising or critically reviewing the article; gave final approval of the version to be published; have agreed on the journal to which the article has been submitted; and agree to be accountable for all aspects of the work.

\section{Funding}

The study was financially supported by National Natural Science Foundation of China (No. 31771163), the key project of science and technology development plan of traditional Chinese medicine in Jiangsu Province (No. ZD202001), and Innovative Project of postgraduate education in Jiangsu Province (No. 021093002404).

\section{Disclosure}

The authors declare that they have no competing interests.

\section{References}

1. Luo J, Feng J, Liu S, et al. Molecular and cellular mechanisms that initiate pain and itch. Cell Mol Life Sci. 2015;72(17):3201-3223.

2. Xu H, Bin NR, Sugita S. Diverse exocytic pathways for mast cell mediators. Biochem Soc Trans. 2018;46(2):235-247. doi:10.1042/ BST20170450

3. Gupta K, Harvima IT. Mast cell-neural interactions contribute to pain and itch. Immunol Rev. 2018;282(1):168-187.

4. Kim HS, Kawakami Y, Kasakura K, et al. Recent advances in mast cell activation and regulation. F1000Res. 2020;9:F1000Faculty Rev-196. doi:10.12688/f1000research.22037.1

5. Yu Y, Blokhuis BR, Garssen J, et al. Non- $\operatorname{IgE}$ mediated mast cell activation. Eur $J$ Pharmacol. 2016;778:33-43. doi:10.1016/j. ejphar.2015.07.017

6. Wareham K, Vial C, Wykes RC, et al. Functional evidence for the expression of P2X1, P2X4 and P2X7 receptors in human lung mast cells. Br J Pharmacol. 2009;157(7):1215-1224. doi:10.1111/j.14765381.2009.00287.x

7. Jacobson KA, Muller CE. Medicinal chemistry of adenosine, P2Y and P2X receptors. Neuropharmacology. 2016;104:31-49. doi:10.1016/j. neuropharm.2015.12.001

8. Franceschini A, Adinolfi E. P2X receptors: new players in cancer pain. World J Biol Chem. 2014;5(4):429-436. doi:10.4331/wjbc.v5.i4.429

9. Kuan YH, Shyu BC. Nociceptive transmission and modulation via P2X receptors in central pain syndrome. Mol Brain. 2016;9(1):58.
10. Inoue K, Tsuda M. Nociceptive signaling mediated by P2X3, P2X4 and P2X7 receptors. Biochem Pharmacol. 2020;29:114309.

11. Tewari M, Seth P. Emerging role of P2X7 receptors in CNS health and disease. Ageing Res Rev. 2015;24(Pt B):328-342. doi:10.1016/j. arr.2015.10.001

12. Broom DC, Matson DJ, Bradshaw E, et al. Characterization of N-(adamantan-1-ylmethyl)-5-[(3R-amino-pyrrolidin-1-yl)methyl]2-chloro-benzamide, a $\mathrm{P} 2 \mathrm{X} 7$ antagonist in animal models of pain and inflammation. J Pharmacol Exp Ther. 2008;327(3):620-633. doi:10.1124/jpet.108.141853

13. McGaraughty S, Chu KL, Namovic MT, et al. P2X7-related modulation of pathological nociception in rats. Neuroscience. 2007;146 (4):1817-1828. doi:10.1016/j.neuroscience.2007.03.035

14. Chessell IP, Hatcher JP, Bountra C, et al. Disruption of the P2X7 purinoceptor gene abolishes chronic inflammatory and neuropathic pain. Pain. 2005;114(3):386-396. doi:10.1016/j. pain.2005.01.002

15. Yang Y, Li H, Li TT, et al. Delayed activation of spinal microglia contributes to the maintenance of bone cancer pain in female Wistar rats via P2X7 receptor and IL-18. J. Neurosci. 2015;35 (20):7950-7963. doi:10.1523/JNEUROSCI.5250-14.2015

16. Ferrari D, Pizzirani C, Adinolfi E, et al. The P2X7 receptor: a key player in IL-1 processing and release. J Immunol. 2006;176 (7):3877-3883. doi:10.4049/jimmunol.176.7.3877

17. Karmakar M, Katsnelson MA, Dubyak GR, et al. Neutrophil P2X7 receptors mediate NLRP3 inflammasome-dependent IL-1beta secretion in response to ATP. Nat Commun. 2016;7:10555. doi:10.1038/ ncomms 10555

18. Kataoka A, Tozaki-Saitoh H, Koga Y, et al. Activation of P2X7 receptors induces CCL3 production in microglial cells through transcription factor NFAT. $J$ Neurochem. 2009;108(1):115-125. doi:10.1111/j.1471-4159.2008.05744.x

19. Parzych K, Zetterqvist AV, Wright WR, et al. Differential role of pannexin-1/ATP/P2X7 axis in IL-1beta release by human monocytes. FASEB J. 2017;31(6):2439-2445. doi:10.1096/fj.201600256

20. Shieh CH, Heinrich A, Serchov T, et al. P2X7-dependent, but differentially regulated release of IL-6, CCL2, and TNF-alpha in cultured mouse microglia. Glia. 2014;62(4):592-607. doi:10.1002/ glia. 22628

21. Bulanova E, Bulfone-Paus S. P2 receptor-mediated signaling in mast cell biology. Purinergic Signal. 2010;6(1):3-17. doi:10.1007/s11302009-9173-z

22. Wareham KJ, Seward EP. P2X7 receptors induce degranulation in human mast cells. Purinergic Signal. 2016;12(2):235-246. doi:10.1007/s11302-016-9497-4

23. Yoshida K, Ito M, Matsuoka I. Divergent regulatory roles of extracellular ATP in the degranulation response of mouse bone marrow-derived mast cells. Int Immunopharmacol. 2017;43:99-107. doi:10.1016/j.intimp.2016.12.014

24. Kurashima Y, Amiya T, Nochi T, et al. Extracellular ATP mediates mast cell-dependent intestinal inflammation through P2X7 purinoceptors. Nat Commun. 2012;3:1034. doi:10.1038/ ncomms 2023

25. Nurkhametova D, Kudryavtsev I, Guselnikova V, et al. Activation of P2X7 receptors in peritoneal and meningeal mast cells detected by uptake of organic dyes: possible purinergic triggers of neuroinflammation in meninges. Front Cell Neurosci. 2019;13:45. doi:10.3389/ fncel.2019.00045

26. Munir MA, Enany N, Zhang JM. Nonopioid analgesics. Anesthesiol Clin. 2007;25(4):761-774. doi:10.1016/j.anclin.2007.07.007

27. Gordon DB. Nonopioid and adjuvant analgesics in chronic pain management: strategies for effective use. Nurs Clin North Am. 2003;38(3):447-464. doi:10.1016/S0029-6465(02)00095-6

28. Vane JR, Botting RM. The mechanism of action of aspirin. Thromb Res. 2003;110(5-6):255-258. doi:10.1016/S00493848(03)00379-7 
29. Kim HM, Shin HY, Choo YK, et al. Inhibition of mast cell-dependent anaphylaxis by sodium salicylate. Immunology. 1999;96(4):551-556. doi:10.1046/j.1365-2567.1999.00729.x

30. Steinke JW, Payne SC, Borish L. Eosinophils and mast cells in aspirin-exacerbated respiratory disease. Immunol Allergy Clin North Am. 2016;36(4):719-734. doi:10.1016/j.iac.2016.06.008

31. Steinke JW, Negri J, Liu L, et al. Aspirin activation of eosinophils and mast cells: implications in the pathogenesis of aspirin-exacerbated respiratory disease. J Immunol. 2014;193(1):41-47. doi:10.4049/ jimmunol.1301753

32. Mortaz E, Redegeld FA, Nijkamp FP, et al. Dual effects of acetylsalicylic acid on mast cell degranulation, expression of cyclooxygenase-2 and release of pro-inflammatory cytokines. Biochem Pharmacol. 2005;69(7):1049-1057. doi:10.1016/j. bcp.2004.12.018

33. McNeil BD, Pundir P, Meeker S, et al. Identification of a mast-cellspecific receptor crucial for pseudo-allergic drug reactions. Nature. 2015;519(7542):237-241. doi:10.1038/nature14022

34. North RA. Molecular physiology of P2X receptors. Physiol Rev. 2002;82(4):1013-1067. doi:10.1152/physrev.00015.2002

35. Jacobson KA, Jarvis MF, Williams M. Purine and pyrimidine (P2) receptors as drug targets. J Med Chem. 2002;45:4057-4093. doi:10.1021/jm020046y

36. Di Virgilio F, Dal Ben D, Sarti AC, et al. The $\mathrm{P} 2 \mathrm{X} 7$ receptor in infection and inflammation. Immunity. 2017;47(1):15-31. doi:10.1016/j.immuni.2017.06.020
37. Hughes JP, Hatcher JP, Chessell IP. The role of $\mathrm{P} 2 \mathrm{X}_{7}$ in pain and inflammation. Purinergic Signal. 2007;3(1-2):163-169. doi:10.1007/ s11302-006-9031-1

38. Itoh $\mathrm{K}$, Chiang $\mathrm{C}$, $\mathrm{Li} \mathrm{Z}$, et al. Central sensitization of nociceptive neurons in rat medullary dorsal horn involves purinergic P2X7 receptors. Neuroscience. 2011;192:721-731. doi:10.1016/j. neuroscience.2011.06.083

39. Dell'Antonio G, Quattrini A, Cin ED, et al. Relief of inflammatory pain in rats by local use of the selective P2X7 ATP receptor inhibitor, oxidized ATP. Arthritis Rheum. 2002;46:3378-3385. doi:10.1002/ art. 10678

40. Ohbori K, Fujiwara M, Ohishi A, et al. Prophylactic oral administration of magnesium ameliorates dextran sulfate sodium-induced colitis in mice through a decrease of colonic accumulation of P2X7 receptor-expressing mast cells. Biol Pharm Bull. 2017;40 (7):1071-1077. doi:10.1248/bpb.b17-00143

41. Rosa AC, Fantozzi R. The role of histamine in neurogenic inflammation. Br J Pharmacol. 2013;170(1):38-45. doi:10.1111/ bph. 12266

42. White FA, Bhangoo SK, Miller RJ. Chemokines: integrators of pain and inflammation. Nat Rev Drug Discov. 2005;4(10):834-844. doi:10.1038/nrd1852

43. Ren K, Torres R. Role of interleukin-1beta during pain and inflammation. Brain Res Rev. 2009;60(1):57-64. doi:10.1016/j. brainresrev.2008.12.020
Journal of Inflammation Research

\section{Publish your work in this journal}

The Journal of Inflammation Research is an international, peerreviewed open-access journal that welcomes laboratory and clinical findings on the molecular basis, cell biology and pharmacology of inflammation including original research, reviews, symposium reports, hypothesis formation and commentaries on: acute/chronic inflammation; mediators of inflammation; cellular processes; molecular

\section{Dovepress}

mechanisms; pharmacology and novel anti-inflammatory drugs; clinical conditions involving inflammation. The manuscript management system is completely online and includes a very quick and fair peerreview system. Visit http://www.dovepress.com/testimonials.php to read real quotes from published authors. 